\title{
Why the Internet is Good for Music
}

\author{
By Thomas Michael Malone
}

\author{
A thesis \\ submitted to the Victoria University of Wellington \\ in fulfilment of the requirements for the degree of \\ Master of Arts \\ in philosophy.
}

Victoria University of Wellington

2017 
"It's better to be a flamboyant failure than any kind of benign success."

- Malcolm McLaren 


\section{CONTENTS}

PREFACE

$\begin{array}{ll}\text { INTRODUCTION } & 3\end{array}$

$\begin{array}{ll}\text { Chapter 1: THE NATURE OF MUSIC } & 7\end{array}$

$\begin{array}{ll}\text { 1.1 JUDGEMENTS OF TASTE } & 7\end{array}$

1.2 FROM SOUND TO MUSIC 12

$\begin{array}{ll}1.3 \text { MUSIC AND OUR EMOTIONS } & 17\end{array}$

$\begin{array}{ll}\text { 1.4 MUSIC AS A SOCIAL BOND } & 21\end{array}$

1.5 IDENTIFYING GOOD MUSIC 26

Chapter 2: THE MUSIC INDUSTRY 32

2.1 THE DEMISE OF THE RECORDIG INDUSTRY 34

$\begin{array}{ll}\text { 2.2 COPYRIGHT AND LAW } & 38\end{array}$

2.3 OVERZEALOUS COPYRIGHT: A Case Study 46

2.4 THE ONLINE MUSIC INDUSTRY 50

2.5 A SIGN OF THE TIMES

Chapter 3: WHY THE INTERNET IS GOOD FOR MUSIC

3.1 THE PRICE OF FAME AT ANY COST 62

3.2 THE COMMODIFICATION OF MUSIC $\quad 67$

$\begin{array}{ll}\text { 3.3 CAN’T BUY ME LOVE } & 71\end{array}$

3.4 CULTURAL CONTAGION

3.5 THE POPULARITY CONTEST 82

$\begin{array}{ll}\text { CONCLUSION } & 91\end{array}$

BIBLIOGRAPHY 


\section{PREFACE}

The purpose of this thesis is to challenge the common notion that the internet has had a detrimental impact on the music industry, and on musicians' ability to generate a viable income while still producing good music. Note, that the following arguments do not automatically extend to the effect that the web has had on books, patents, films, journalism or any other medium. The reason for this is because these different disciplines have individual characteristics that make them respond differently to the same socio-economic pressures. However, on the same token, it does not necessarily follow that the conclusions reached here are inapplicable to other activities: perhaps what is true for music in the following pages is also true for e.g. photography. Furthermore, I am not advocating for a free-for-all internet where behemoths like Google, Amazon and Facebook get to do whatever they wish. Although I am intrigued by such matters, the constraints of both time and space allow me only the possibility to focus on the subject that I am most familiar and passionate about. Furthermore, because I am painting a broad picture which encompasses many intellectual disciplines, many of which I am not an expert in, this work is to be considered more on the consistency of the overall argument rather than the minutia of its individual parts. 


\section{INTRODUCTION}

Being not only an avid music fan but a musician myself, I find it difficult to reconcile the view that 'the internet has ruined the music industry' with the fact that our ability to experience music in all its forms has never been greater. It is quite extraordinary that this paradigm changing technology, that has made it possible for performers to bypass the traditional gatekeepers and market themselves directly to a global audience, is still being been treated like a scourge upon the music industry.

I do not deny that there are casualties in this transition from the analogue to the digital world: older musicians who formulated contracts and had expectations and arrangements made in the era before the internet have been negatively affected by this technological evolution. The legions of intermediaries including both large and independent record labels, CD manufacturers, record store owners, large scale rights holders and everyone else along the music supply line have also been affected. However, the same could be argued for the poor folks who invested in a taxi license prior to Uber's emergence and those who sold carts and wagons when horses began to be replaced by the Tin Lizzies rolling out of the Ford Motor Company's assembly line in 1908: transition costs.

The argument in defence of the music industry essentially rests on the view that, because people pirate copyrighted material on the internet with impunity, musicians have lost the ability to generate a living from album sales. This loss of revenue has all but turned the business into a mere shadow of its former self and forced the large labels to consolidate their respective positions, through some high-profile mergers and acquisitions, that resulted in the industry becoming highly centralised. 
The internet's effect on music can be characterised as such: due to a considerable drop in revenue, labels have had fewer resources available to take risks on more aesthetically challenging artists. Labels have, therefore, been obliged to focus on performers who have mass appeal. Consequentially, musicians are less able to push the creative boundaries if they wish to be signed to an influential label and pursue their craft as a career. As a result of this push towards the aesthetic centre, music has become more homogenous. So, not only has the liberal nature of the internet affected the music industry's supply chain, all the way from record store owners to musicians themselves, but it has had a damaging effect on the quality of music. I will define those who hold this view as taking the protectionist position.

Protectionists: a loosely clustered set of individuals who feel that copyright laws ought to be strengthened and enforced, and that the internet ought to be regulated to the extent that piracy is not facilitated or allowed by search engines or internet service providers

Protectionists advocate for governments to take a more active role in protecting the rights of artists and rights holders not to have their work distributed online without their consent. They see music as being the product of the musicians' labour and, therefore, deserving of the same rights and legal privileges afforded to other creators whose goods and patents are protected by legislation. The typical protectionist mantra is: 'calling music theft 'file-sharing' is like stealing a car and calling it 'vehicle-sharing." I define this term loosely, because in every loose affiliation of people (such as in a political movement) there are many varying points of view, but they are nonetheless definable as a group because there also tend to have at least some core values unifying them. 
I will show that because the bulk of the recording industry had already been appropriated by financially motivated decision makers before online piracy became an issue, producing music that appeals to the lowest common denominator cannot be blamed on illegal downloads. I will argue that the internet materialised at the right time and that it has been the saving grace for all music fans, as peer-to-peer filesharing is one of the many tools that can be used by musicians who had little chance of being signed by these profit driven corporations.

Furthermore, I will show that over-zealous copyright enforcement and price walls are detrimental not only to music's creativity, but also to artists' means of marketing their work to promote live shows and other potential revenue streams, and more importantly: for the internet's neutral status. The latter has far ranging and potentially dire consequences that stretch well beyond the music world. This ought to demonstrate that on balance, letting music spread online is considerably more favourable than what is being advocate for by protectionists. I will characterise this stance as the liberal position.

Liberals: those who take the view that (authorship aside) online music should not be subject to the current laws that govern its ownership in the proprietary sense of the word, and that copyright restrictions should be relaxed

It is important to note that this liberal position is not a libertarian one, for the simple reason, that the latter view is usually characterised as advocating for strong property rights, while I am doing the opposite. However, I do not argue that musicians should not get paid if their music is used by third parties, instead I will be arguing for copyright rules that reflect the present needs of musicians and the public.

I will also discuss why creating music for mass appeal is not only aesthetically inferior, but why it has a corrosive effect on the arts, culture and society. I will 
demonstrate that those musicians worthy of our admiration shall get their due respect not through the enforcement of overzealous copyright laws, but by our ability to discern beauty and the generosity we show to those who create it.

What I present does not purport to be a guide to navigating the fickle world of the music industry: I am proposing ideas for how music and musicians might best be served by the internet and its rapidly growing influence on so many aspects of our lives. 


\section{Chapter 1: THE NATURE OF MUSIC}

To carry out what I propose in my introduction, I will first need to show that where music is concerned, qualitative distinctions can be made. Not being able to demonstrate that aesthetic evaluations of taste are anything other than subjective might lead my detractors to suggest that beauty reverberates in the ear of the beholder. This would make it difficult to claim that some musicians are worthier of our admiration than others. I will, therefore, start by giving an account of what constitutes a judgement of taste according to David Hume. I will then provide empirical evidence supporting Hume's claim regarding our social and aesthetic proclivities vis-à-vis music. This will show that music is an integral part of our human identity like language, friendship and love. This should demonstrate that the protectionists' attempts to subject music to a model wherein traditional market forces can determine a work's intrinsic worth is, and always has been, flawed. After-all, demanding to be paid for your music is like expecting to be paid for love.

\subsection{JUDGEMENTS OF TASTE}

David Hume in Of the Standard of Taste (1757) begins by declaring, that: "Beauty is no quality in things themselves: It exists merely in the mind which contemplates them; and each mind perceives a different beauty.” (Hume, 268) In other words, piano concertos, without a human mind to perceive them, consist of nothing other than soundwaves rebounding off chairs and walls. Furthermore, because we are all individually different, both genetically and in terms of what we have seen and done, we each experience aesthetic phenomena in a unique way. This also means that if we listen to a particular concerto at a future time, it will be a different 
experience from the first. This is because aesthetic experiences are subjective. Hence the saying: 'beauty lies in the eye of the beholder'.

However, if we reflect on this idiom, it may lead us to suppose that Beethoven and Justin Bieber are of the same ilk. Hume remarks that "we pronounce without scruple the sentiment of these pretended critics to be absurd and ridiculous" (Ibid, 269). What Hume means is that while tastes might be subjective, it does not necessarily follow that they are relativistic.

The central purpose of Hume's essay is to explain away this seemingly paradoxical situation. Christopher Janaway proposes that "Hume's problem is to avoid relativism without retracting the point that judgements of beauty rest upon sentiments, or the point that sentiments represent nothing in the objects" (Janaway, 123). Hume suggests that many judgements of taste appear to be based on conventions rather than concrete rules. These "general rules of art", as Hume refers to them, are "founded only on experience and on the observation of the common sentiments of human nature" (Hume, 270).

Hume's claim is contingent on there being a relatable degree of uniformity in the human faculties across our species. The idea that aesthetic experiences are not entirely different from one individual to the next could explain why a consensus on aesthetic judgements is possible. But, if that is the case, it makes it more difficult to understand why anybody even bothers listening to Justin Bieber when they could instead be listening to Beethoven. That is, it fails to clarify why the prevailing orthodoxy suggests that the latter is clearly superior to the former. Simply because we all hear a minor chord and perceive music in chunks similarly across different cultures, it does not necessarily follow that a normative judgement can be made as to a 
musician's quality, for, as every philosopher knows, Hume himself had earlier pointedout in A Treatise of Human Nature (1739) that one cannot get an ought from an is.

Hume supposes that artworks have "particular forms or qualities" that "are calculated to please, and others to displease; and if they fail of their effect in any particular instance, it is from some apparent defect or imperfection in the organ” (Ibid, 271). Therefore, if a subject is unable to discern beauty in a beautiful artefact it is because of a shortcoming on their part. This implies that "particular forms or qualities" are inherently beautiful (or repulsive), but only insofar as there is a mind to contemplate them that is free of "apparent defect".

Unfortunately, from a philosophical point of view this is akin to declaring that you see angels, and that the only reason others do not, is because their minds are defective. It is, as Karl Popper would suggest, an unfalsifiable claim. This highlights the circularity of Hume's argument. While we can agree objectively to the degree to which a liquid might be corrosive by assessing its acidity, I am unaware of any such litmus test where sentiments are concerned. However, this does not mean that what Hume asserts is false: for it does seem intuitively correct.

Although intuition is often seen as a dirty word in philosophy, it should not be considered with the same degree of hostility when questioning whether we have a behavioural predilection towards something as when it is used in a strict epistemological context. Besides, this does seem to be supported by the ease with which we do seem to come together to reach a consensus on what we deem to be good. Should one wish to challenge this view, might I suggest that they go down to their local pub and declare to their fellow patrons that the graffiti on the men's room wall is more 
beautiful than the Sistine Chapel, and hear what they have to say about that: but that would just be "absurd and ridiculous".

Hume proposes that the 'test of time' is the only real means of assessing an artefact's true aesthetic value. "We shall be able to ascertain its influence" and the "durable admiration" of a work of art only if it has "survived all the caprices of mode and fashion, all the mistakes of ignorance and envy.” (Ibid, 271) Unfortunately, because we do not have four-hundred odd years up our sleeve to discern whether the song we just heard and enjoyed is in fact terrible, Hume emphasises the importance of the critic.

A good critic should have been appropriately educated and been born with a good sensory apparatus and "that delicacy of imagination, which is requisite to convey a sensibility of those finer emotions" (Ibid, 272). Should our critic have these learned and inborn qualities, they would be the most qualified to make the best aesthetic judgements. Consider that if you were to judge perfumes, you would need to have an elaborate and highly complex sense of smell (so you could not be a smoker or someone who works with volatile chemicals), and you would need to have been educated in the identification of different fragrances. One would also need to have a good knowledge of all the different perfumes available if they were to identify whether a supposedly new product is in fact an imitation of an existing one. They would also need to be free of biases: you can't have someone in the employ of Yves Saint Laurent pertaining to give objective judgements over the quality Givenchy perfumes. Hume:

\footnotetext{
Strong sense, united to delicate sentiment, improved by practice, perfected by comparison, and cleared of all prejudice, can alone entitle critics to this valuable character; and the joint verdict of such, whenever they are to be found is the true standard of taste and beauty.
} (Hume, 278-279) 
Hume insists that good critics "are easily to be distinguished in society, by the soundness of their understanding and the superiority of their faculties" (Ibid, 280).

The significance that Hume places on expertise in judging the arts could be at odds with my argument that regular people (or the vulgaris, as he would put it) know beauty when they see it. In fact, it seems to strengthen the view that we need music industry experts to discern what is praiseworthy, or good musicians may genuinely find themselves obscured by the overwhelming number of mediocre performers vying for our attention. Janaway correctly asks whether true judges are recognised by their superior judgements, as Hume supposes, or whether "judgements (are) superior simply because true judges make them?" (Janaway, 126). Let me unpack the last point to make it as clear as possible:

Do we recognise good art experts because their judgements consistently reflect our own intuitions about the works in question?

Or

Are our opinions formed by experts suggesting what they believe to be good?

The latter implies that our artistic tastes might be socially constructed and that we like the Sistine Chapel frescos better than toilet door graffiti because of culturally determined, rather than innate, aesthetic preferences. And, that we may think that we like something intuitively, when, really, we have been socially conditioned to prefer what we think we like.

I should find it uncontroversial to suppose that most South Koreans prefer Kpop over reggae, or that Indians have a penchant for Bollywood movies whilst most Westerners cannot stand them, or even that punk rockers probably do prefer toilet wall graffiti instead of that 'pompous middleclass crap' on the Vatican ceiling. It would, 
therefore, suggest that if beauty were objective and universally appreciable (because of the uniformity of our sensory perception: more on this soon) that we would all be enjoying the same music and art. Instead, we seem to gravitate towards our individual cultural norms. Even within one's culture one tends to gravitate towards the music of one's generation. This certainly does lend credence to the belief, that, whilst people might perceive external stimuli in much the same way, music might be beyond that which could be considered as being good or bad on aesthetic grounds.

If one is to support Hume's claim that good critics are identifiable by the veracity of their judgements over time, one would need to present scientific evidence showing that there is a relatable degree of uniformity across individuals' appreciation of aesthetics. Failing to establish good music as having biological constraints would leave my thesis open to a wide range of arguments from the standpoint of cultural relativism. These could be exploited by protectionists to justify their attempts to appeal to the lowest common denominator in order to sell as many records as possible. I must, therefore, show that there are objective criteria available to define what good music is. This means I must present a plausible theory for how music came about, why we have an interest in good music and what good music is.

\subsection{FROM SOUND TO MUSIC}

In 2012, archaeologists discovered the remnants of flutes dating back 40,00042,000 years ago. They were found in a cave near Blaubeuren in the Swabian Jura of Southern Germany. They are known as the Geißenklösterle flutes. The flutes are the oldest artefacts discovered to have been identified distinctively as musical instruments. This is of considerable significance because it means that they represent 
the oldest evidence, yet, that we were already creating music in the Upper Palaeolithic. ${ }^{1}$ As I'm sure you will recall from your music classes at school, playing the recorder is not as simple as clapping and singing. This might lead us to suppose that we were making more basic forms of music, like drumming, for a considerable period prior to these flutes' incarnation.

The earliest direct evidence of musical scales is the flutes which were found at the Neolithic village of Jiahu, in central China, dating back 8,00o-9,0oo years ago. These were fashioned from the wing bones of cranes (bird bones being porous, are more readily turned into instruments). One was found in such pristine condition that it can still hold a tune to this day. Because of the careful positioning of the holes, we were able to determine that these early performances made use of the pentatonic scale, which represents five notes per octave. ${ }^{\mathrm{I}}$ This means that the instruments were not used to make random cacophonies, as a child might with an improvised wind instrument (like a bottle), but that there was clear intentionality and that it was complex. When the Jiahu flutes are considered alongside the Geißenklösterle flutes, it strengthens the hypothesis that this musical culture, a culture of performance, must have been widespread and probably quite firmly established even as far back as when woolly rhinoceroses and mammoths still roamed Eurasia - which is quite remarkable if you stop to consider it. This implies that along with tool making, hunting, making fire and language, music might be one of those things that all people - no matter where they are - do and have done for possibly hundreds of thousands (or millions) of years.

Musicologist Paul Griffiths, in A Concise History of Western Music (2006), delves deeper into the artistic temperaments of our ancestors: "Playing a flute, a

\footnotetext{
I The Jiahu are the first ostensible display of scales, and the pentatonic scale is what is used in most modern pop songs.
} 
musician must also have pondered how to end, and so been faced with questions of finding the properly conclusive note, therefore of harmony, and of accomplishing the transition back to silence" (Griffiths, 3). This is indicative of the mental complexity of our forebears, and the role that music might have played in developing our neural pathways, and perhaps even our abstract sense of time. Naturally, we cannot know any of this for certain, but I will show that there is solid evidence indicating that aspects of our brains appear to have developed for the purpose of processing music, which may or may not be linked directly to our linguistic development. This would indicate that our appeal for music could potentially be reflexive, like language and love.

Perhaps Homo erectus spent their evenings drumming around their campfires, or maybe it all began a lot earlier with $H$. habilis imitating bird calls. We will never know for certain how long we have been enjoying tunes for, but I suspect that ancient music (and art in general) was used for a multitude of reasons in a multitude of contexts, just as it is presently. These range from hedonistic drug fuelled dance parties in the middle of the Nevada desert, to church choirs and the singing of lullabies to accompany children into sleep. Music is a ubiquitous and popular (possibly crucial) aspect of our human identity. Therefore, if I am to build a case for music being instinctive and an integral aspect of human nature, it would probably be a good idea to get a basic understanding of how we perceive music and what effects it has on our psyche, and ultimately our behaviour.

James Beament makes the novel point in How We Hear: The Relationship Between Music and the Hearing Mechanism (2001) that if people with normal hearing heard things differently "there would be no basis for criticism or review, or indeed for music itself" (Beament, 147). The ear as a mechanical apparatus is relatively straight forward. Beament states that we know quite a lot about how the ear works and how 
the soundwaves are converted into electric pulses by the vibration-sensitive cells. We also know "a great deal” about how these pulses travel up the nerves, as all nerves seem to work in pretty much the same way. But, once these pulses travel into the cortex, our understanding of how these electric signals affect us becomes comparatively opaque.

The hearing system started out hundreds of millions of years ago as a mechanism for detecting vibrations to alert our distant ancestors of impending dangers. Incidentally, we still get a jolt of adrenaline when silence is interrupted by a loud noise. The next step was an apparatus which would assess the size, or volume, of the vibrations to determine whether the danger was approaching and, therefore, becoming louder or going away and consequently getting fainter. Then came what we might call the 'Dolby Surround system' for determining the direction from which the sound came: this is invaluable if you need to figure out which direction to scram when you hear a very loud lion's roar.

According to Beament, for nature to mould this "direction-finder" with the sort of ear we have meant it was quite a convoluted and messy process. We had a hearing system that evolved to hear sound from all directions at once: in essence, it was like converting a mono recording into stereo and then adding Dolby Surround 7.1 to the mix. This is what spurred the complex development of our auditory cortex. "It needed a very complicated set of automatic units in the brain to determine sound direction" which "required the ears to signal the sound in particular ways and in great detail, so that the units could divine direction and produce appropriate reactions." The evolution of our auditory cortex (and many aspects of the adjoining hardware) was driven by our brain's necessity to convert these soundwaves into the multi-directional sensations we perceive (Ibid, 90-94). This would indicate that there is a strong argument for our complex internal sound processing mechanisms to have been driven, at least initially, 
by clear cut natural selective pressures: our ancestors needed to have complex hearing just to survive the brutality of life in a state of nature.

Evidence suggests that the basic mechanical components of hearing (those processes that capture the vibrations and converts them into pulses) are more or less the same across all people (and presumably animals) deemed to have normal hearing.

While one could suppose that the brain's auditory mechanism behaves predictably across different individuals, one may be less convinced that different environmental inputs will produce the same sensory appreciation. I imagine that all would agree that if someone grew-up in the Bronx listening only to hip hop, their experience and enjoyment of klezmer would be drastically different to that of a 94year-old Jewish woman who was born in Krakow.

This means that if we are to get a broad understanding of how music affects us we need to consult what science has to say on the matter. This is important to help us understand whether there are some universally appreciable underlying musical patterns that we tend to find more pleasurable - irrespective of our cultural background. Doing this is necessary if I am to show that despite relative musical preferences, musical excellence is, in and of itself, objective. I stress preferences because to prefer something is not to agree that it is better: I might prefer a 1978 Trabant because I think the Soviet era retro-chic looks cool and quirky, but there is little denying that a brand-new Mercedes-Benz is, objectively speaking, a better car because it performs the functions that we associate with an automobile with considerably less unpredictability than we might expect from its East German counterpart. We will return to this idea in the context of music, later. 


\subsection{MUSIC AND OUR EMOTIONS}

Silvia Bencivelli in her book Why We Like Music (2007) explains that compared to the average population, musicians have a larger amount of grey matter in the part of the audio-cortex which processes incoming auditory information called Heschl's Gyrus. In addition, studies comparing individuals who received musical training in childhood to those who did not, and professional musicians with amateur ones suggest that there might be a genetic component to musicality.

Bencivelli suggests that "rather than their quantity (of brain cells) increasing by playing scales and arpeggios, it could be that their number determines the desire to study music". This would not mean that our brains remained unmodified by exposure to music, "quite the contrary: the brain is plastic and adapts itself to our needs." Therefore, the earlier we start learning music the larger the area of the brain dedicated to musicality becomes. In the conclusion to a 2001 study published in American Journal of Medical Genetics the researchers noted: "The most reasonable view of the existing data is that certain early childhood musical exposures increase the probability of AP (absolute pitch) in genetically susceptible individuals". ${ }^{2}$ So, while musically inclined people might be born good musicians are made.

Regarding the question of music's emotional impact on us, it appears that a "very old" part of the human brain called the limbic system is stimulated when we are exposed to music. "Its function is to reward the individual when he does something useful for himself or the species - like eating and reproducing - by means of a hormonal messenger called dopamine” (Bencivelli, 43-46). 
Amotz and Avishag Zahavi in The Handicap Principle: A Missing Piece of Darwin's Puzzle (1997) put the case forward for why artistic behaviour should, at least in theory, convey a biological advantage:

\begin{abstract}
Whatever humans gain by appreciating and creating art, its value must have an apparent and concrete basis: to claim that its value is 'spiritual' or 'aesthetic' is simply to miss the point, since such 'feelings' and 'spiritual needs' too evolved for specific reasons. How then, could people have benefited from their first attempts at art? (Zahavi \& Zahavi, 224)
\end{abstract}

Pleasurable responses are nature's way of incentivising beneficial behaviour. So, from an evolutionary stand-point it would indicate that there might have been some biological benefits for our ancestors to have adapted musicality into their DNA.

Archaeologist Steven Mithen in The Singing Neanderthals: The Origins of Music, Language, Mind, and Body (2005), proposes that musicality preceded language: "while both language and art are most likely restricted to Homo sapiens, musicality has a significantly earlier appearance in human evolution and was utilized by a wide range of hominin ancestors and relatives."3

This position is mirrored by John Powell author of Why You Love Music: From Mozart to Metallica - The emotional Power of Beautiful Sounds (2016), who explains why musicality might have preceded our use of words: "Language could only have been developed long after we evolved the vocal equipment required for speech, so there must have been a period of time when early humans used their voices, without words, to communicate emotions”. (Powell, 50) If you've ever been adopted by a cat, you will know that they are very good at conveying their sentiments with their meows (usually hunger and a desire to have doors opened for them). So, this is probably not unique to humans. 
A 2016 comparative study of more than 6,000 languages demonstrated that a considerable proportion of the most common and basic words (such as nose, stone, drink, red, bite etc.) are spoken using the same respective noises - regardless of continent or language group. 4 Therefore, it could be supposed that if language is this heavily anchored in our DNA, then musicality, which is demonstrably older as it appears to be necessary for language, must itself be even more deeply integrated in our behaviour.

Powell believes that the connection between speech and music happens at an emotional level: "A growing amount of evidence shows that there are similarities between the ways we perceive emotion in both speech and music." Powell continues: "brain scans have shown that we use many of the same areas of the brain when we are judging the emotions being expressed by music and speech.” (Ibid)

There is mounting evidence showing that where basic feelings are concerned, particular tunes appear to provoke specific emotions in a cross section of the human population. These tests have been repeated on young children (five and ten-year-olds), people who have had extensive musical training, people who haven't, both men and women, and even people from an obscure African tribe called the Mafa who reside deep in the Congo, that acted as the study's experimental control, as they had never been exposed to music that was foreign to them. 5

It should be noted that music does not automatically get converted into actual emotions: rather, we manipulate noise to recreate the biological sounds that we associate with specific emotions. Indeed, music may entrain our sentiments in a direction but we are not 'Manchurian Candidates' who systematically fall under the 
spell of a particular tune and robotically assimilate the emotional cue we hear: our complex self-aware and reflective minds act as a buffer between hearing and acting.

The person listening to me plucking a D-minor on my guitar recognises the sound as being indicative of sadness without necessarily being compelled to burst into tears (at least, I should hope not). By plucking my guitar I am not creating sadness: I am merely exploiting our biological sensitivity to the sorts of descending soundwaves that we reflexively associate with sadness: like weeping and other such laments. I know from personal experience that certain compositions can be of such delicacy as to bring one to tears; this is what may be referred to as experiencing beauty, but even then, one would need to be in the appropriate frame of mind or context to appreciate it as such.

Powell: "Music is not necessary for survival, but emotional responses are, and music creates emotional responses." (Ibid, 56) Since music can convey emotions it would suggest that it is our species' emotional lingua franca - providing that there is some degree of uniformity in how we experience our emotions across our species, and many studies show this to be a fairly strong conjecture. ${ }^{6}$ This is because humans are not so biologically different as to have painful stimuli activate entirely different parts of the brain in different individuals of different cultures. In fact, the universality of our basic emotions underlies most of the arguments against moral relativism.

In her book Herding Hemingway's Cats (2016) geneticist Kat Arney explains that due to biological bottlenecks in our not too distant past (such as the Lake Toba volcanic eruption 70,000 years ago which devastated much of Earth's life), we have a relatively small affective population, which means that "we haven't managed to accumulate significant amounts of genetic variation between different groups of people across the globe”. Arney declares that this lack of diversity means that as 
humans "we're all boringly similar at a genetic level”. Actually, it's a lot worse than that: "an onion has five times more DNA than you" (Arney, 26-27).

In Music, Thought, and Feeling (2015) William Forde Thompson explains that beyond conveying the most basic feelings (e.g. minor chords sounding sad), there have been numerous studies indicating that specific musical patterns stimulate more complex “secondary emotions”. Primary emotions, such as "happiness, sadness, anger, and fear" are those universal feelings that people readily empathise with regardless of cultural background: such as the fear we might experience if we came face to face with a tiger, or the joy we might feel when a child smiles at us or still, the expletive laden rage you express after stubbing your toe.

Secondary emotions are the more nuanced responses we experience from socially constructed cues, such as the shame most of us in 'civilized' societies have surrounding public nakedness: a sense of shame that tribal people would no doubt consider - not only prudish - but oppressive (just as a Finn might when seeing a woman wearing a veil). Another such example is the sense of pride one may feel after killing an elephant: an act that others would consider repugnant. Thompson maintains that these subjective feelings would appear to be comprised of different blends of primary emotions. These, it would seem, can only be truly understood through relevant cultural insight (Thompson, 170-171).

Therefore, it would be hard to deny that having the ability to convey emotions is beneficial to our survival, which means that there are good reasons to suppose that there is a deep and ancient connection between music and our species. This could lead us to suppose that music is something more than the typical product that can be packaged and commodified like nappies or a car insurance policy. 


\subsection{MUSIC AS A SOCIAL BOND}

Now, that I have shown that music can not only be used to communicate emotions across socio-temporal barriers, I will show that it also has the added evolutionary advantage of forging social bonds. Dunbar in Human Evolution (2014) proposes that our default social network consists of roughly 150 individuals with which we habitually do reciprocal favours for. Interestingly, this also reflects the average hunter-gatherer tribe size. Chanting and drumming around campfires in the Pleistocene would have been a very effective way of forging bonds with our kin to build a group identity.

Dunbar, in conjunction with work done with other evolutionary psychologists, has shown that when agreeable music is listened to, euphoria inducing endorphins are injected into our opiate receptors:

\footnotetext{
Endorphins (and the endogenous opioid system (EOS) in general) are involved in social bonding across primate species, and are associated with a number of human social behaviours (e.g., laughter, synchronized sports), as well as musical activities (e.g., singing and dancing). Furthermore, passively listening to music engages the EOS, so here we suggest that both self-other merging and the EOS are important in the social bonding effects of music.7
}

Another study associated with Dunbar's work showed that singing also has an "icebreaker effect" which acts in "promoting fast cohesion between unfamiliar individuals, which bypasses the need for personal knowledge of group members gained through prolonged interaction". ${ }^{8}$ Again, this is nature incentivising people to do what is best 
for their biological fitness. By rewarding specific behaviours with chemicals that make us feel good, nature is actively encouraging cooperation, kinship and love.II

Having evolved in complex communities in which individuals have competing agendas and interests, there is a clear need to create mutual empathy and cooperation to reduce interpersonal friction, because as we all know: familiarity breeds contempt. Laughter and music might, therefore, be valuable tools to that end.

If no bond is greater than that of mother and child: it should be unsurprising to discover that young children appear to be preconditioned to music, in ways that they are not to so many other activities that people grow-up doing. Thompson cites numerous studies showing that infants are endowed with "frequency coding mechanisms and multisensory connections" and "a remarkable ability to discriminate pitches and rhythms, which is one of the most basic prerequisites for music appreciation”.

Infants also have a significant predisposition for consonant intervals compared to dissonant ones within months of being born, which suggests that this is unlikely to be a learned behaviour (notwithstanding the possibility that these traits might have been acquired in the womb). Infants are also "attuned to the connection between rhythm and movement, implying that the two phenomena are naturally intertwined”. Just as hand gesturing is an integral part of speaking, so is movement in music, like dancing or even just tapping one’s foot. ${ }^{I I I}$

II So much for the dystopian nightmares of eugenics and 'survival of the fittest' stemming from Darwinian philosophy.

III I have been unable to find evidence of a culture which has music without dancing, or for that matter, which has neither, and I have searched the literature far and wide. All that is required to falsify my entire thesis is to provide such an example. 
Thompson: "Similar predispositions and skills emerge in infants across cultures, providing the foundation for universal aspects of musical structure.” But, as with all heritable behaviours it would not be wise to suggest that the mechanism for this comes pre-packaged like a Sony Walkman and a box of cassettes: "musical development occurs through this constantly evolving interaction between nature and nurture" (Thompson, 108-109). A very good example of the synergy between nature and nurture in this context is how the auditory shape (or melody) of a neonate's crying is shaped by its mother's language. 9

According to Darwin's theory of evolution, our phenotypes are open to scrutiny by others for the purpose of identifying the most beneficial traits for the group and/or a particular individual. ${ }^{10} 11121314$ Sexual selection is typically represented by the peacock and the extravagant performances he puts on for his peahen. Unfortunately, this cliché is a particularly bad example for describing what goes on in the mating behaviour of humans: we are far more complex intellectually and culturally than any peafowl (or any other animal, for that matter) and, crucially, we are a societal species while peafowls are solitary. Therefore, in most instances the traits favoured by humans must convey an adaptive advantage to the group, which is hierarchically organised. The traits selected are therefore a lot more conservative and indisputably less extravagant than those of that fanciful fowl.

Art making in general is thought to be quite a good indicator of one's capacities, because developing these different talents successfully enough to impress people is a 'high cost' enterprise. This means that such activities tend to be particularly difficult to fake: being able to fake that you are good at art means that you have to, well, be good at art. and that takes a lot of time, skill and dedication. Making art, such as singing or weaving stunning baskets and carving intricate designs on the side of drums 
and other tools, can be materially and temporally costly. Thanks to an artefact's attributes, such as the rarity of the materials used to create it and its complexity, we can evaluate the labour cost, resourcefulness and intellectual skills of its creator (or creators). Because, these are qualities that we admire both individually and as a group, we will hold their makers in higher esteem: elevating their status in the hierarchy. This is why developing one's musical skills and performing live is a good way of advertising one's personal qualities: from a biological standpoint it is a good 'fitness indicator'.

The costliness of such activities was theorised upon by Amotz Zahavi who conceived of the 'handicap principle' in 1975. The high cost of having and maintaining large tails, or partaking in behaviours that squander energy, is indicative of resourcefulness, because it means you have energy to waste. This might explain why top musicians and artists are not only revered, but why people throw themselves at them. And if you can't do it, the next best thing is to buy it: being able to afford to hang a Jackson Pollock above your fireplace or have The Rolling Stones play at your $54^{\text {th }}$ wedding anniversary shows-off the valuable resources you can afford to squander.

It would be so easy to take a dim cynical view of music (and art in general) as being a crude fitness indicator, but that would be a grave mistake. Considering music solely on its biological merits would be the same sort of mistake that enthusiasts of neoclassical economics do when justifying their cold-heartedness as being in the interest of the 'survival of the fittest' and, therefore, in harmony with nature, or morally permissible because it somehow appears to be consistent with a cheetah killing and eating a lame antelope. Not only is this view too simplistic, but more importantly, subscribing to such an idea would be to commit to a naturalistic fallacy. 
Quite in contrast to a cold calculated activity with selfish ends, the view I present elevates art's appreciation to the realm of the feelings we associate with friendship and communing with others. People form group identities through music: punks, cowboys, goths, crooners, ravers etc., all connect and identify with their kin not only by wearing similar fashions, but also through a shared sonic aesthetic. But it goes well beyond style, venturing deep into activities of substance: religious communities, political movements, generations and even countries have their respective anthems. Music is an integral aspect of the human condition: this is why it is not implausible that we might have been conditioned to identify good music and good musicians who have artistic integrity when we hear them.

\subsection{INDENTIFYING GOOD MUSIC}

Now, that I have demonstrated that there are good reasons for supporting the view that musicality presents some profound benefits at both a social and a biological level, and that we hear its basic constituents with a basic degree of uniformity across different human populations, I would like to show that we can spot talent when we see and hear it.

This is necessary to answer Janaway's question pertaining to Hume, about whether we recognise the good experts because their verdicts consistently reflect what we intuit to be worthwhile, or, whether our tastes are formed by experts suggesting to us what is good. I do not wish to suggest that protectionists necessarily hold the latter view, but this could be an argument from cultural relativism challenging my hypothesis that good musicians are objectively discernible. 
I will later be showing that being able to make these qualitative distinctions will put us in a much better position to reward those worthy of our praise rather than those who are merely good at using marketing tools and producing formulaic music designed to appeal to the lowest common denominator. We will see that the latter is used by record labels who care only about extracting money from consumers, and that these tactics have a negative effect, not only on the quality of the music being published, but also on the internet's neutrality as well as on listeners' behaviour and their mental health.

Most musicians are unaware of the underlying psychological reasons for why they make music. Indeed, this is because there too is great joy in making, finishing and presenting songs. As we saw above, the euphoria inducing chemicals released in our heads is its own reward. This sense of accomplishment and joy is what incentivises artists to persevere through all the personal sacrifices necessary to master their craft.

This naturalist approach, of connecting art to our psychological yearnings, is nothing new: Aristotle put this idea forward in Poetics, suggesting that the reoccurring patterns that we see emerging from the plots of the most popular plays were indicative of a shared human nature. We also saw Hume taking a definite position on the universality of aesthetic appreciation by asserting that "the general principles of taste are uniform in human nature". This is necessary in the context of his theory or there would be no reason for supposing that a consensus could ever be reached, otherwise. Kant, in $\S 40$ of the Critique of Judgement (1790), raises the propos of taste’s universality that he refers to as our sensus communis. And, let us not overlook Beethoven's poet of choice for his ninth symphony's fifth movement: Friedrich Schiller, who spoke of our aesthetic "play drive" in his excellent philosophical writings. These theories have only recently been able to be tested, thanks to science finally 
catching up to these visionaries in the way of evolutionary psychology. Denis Dutton's The Art Instinct (2009) puts the above theorist's ideas (and more) in the context of what modern science has unearthed, with regards to our evolved character traits.

Philosopher Kathy Higgins lists sixteen universally observable structural components that she refers to as "processing universals", which have been identified as characterising the properties of music:

1) We distinguish signals from noise. 2) Sounds that are candidates for being incorporated into human music must be within the range of human pitch perception. 3) We perceive musical information in chunks. 4) We perceive a tone an octave away from a given tone as effectively the same tone. 5) We stretch octaves. 6) We organize musical signals in terms of melodic contour. 7) Melodic fission occurs. 8) We accept an acoustically deviant tone as the nearest pitch in the scale, so long as it is sufficiently close. 9) We more easily remember intervals and sequences of tones with frequencies in small-integer ratios with one another. 10) Temporal patterns are more important for processing and remembering musical sequences than are specific timing cues. 11) We utilize frameworks of discrete scale pitches, typically with uneven step size. 12) Scales tend to be restricted to five to seven tones. 13) Pitches are organized hierarchically within the scale. 14) The temporal lengths of tones are typically uneven. 15) Rhythm is more basic than pitch for making judgments of similarity of musical pattern. 16) Tempo-keeping seems to be proportional, on the basis of low integer ratios. ${ }^{15}$

These seem to indicate that there is universal 'musical grammar' that could be understood and used by people as a common ground from which to, not only experience music in a relatable fashion, but from which to judge musical performances. This musical grammar appears to relate back to music's synergy with our emotions. 
Patrick Gomez and Brigitta Danuser explain that "the relationships between musical features and experienced emotions corresponded well with those known between musical structure and perceived emotions." This suggests that "the internal structure of the music played a primary role in the induction of the emotions in comparison to extramusical factors" ${ }^{16}$ These findings are corroborated by Powell in his chapter 'How Musicians Push Our Emotional Buttons' (Powell, 192-213).

Powell discusses people's fondness for pattern recognition: "Since the ability to recognize patterns is a very efficient way of making sense of our surroundings, our brain has evolved to make us feel rewarded whenever we successfully identify one." Powell continues: "We are stimulated by complexities in a pattern or combinations of patterns. Unexpected breaks in, or changes to, pattern also add extra interest and increase arousal.” (Ibid, 224).

Valorie Salimpoor et al. in a 2011 study shows that this pattern seeking behaviour adds to what was earlier discussed regarding the neurochemical rewards we get from listening to music: "The anticipatory phase, set off by temporal cues signalling that a potentially pleasurable auditory sequence is coming, can trigger expectations of euphoric emotional states and create a sense of wanting and reward prediction."17 These audible cues provide us with the underlying structure for a universal language that we are all capable of tuning into. Music having these underlying patterns also means that we are not only able to distinguish it from mere sound, but that we have the means of separating good music from bad.

These underlying musical structures that stretch across all musical genres are not what we immediately respond to. What we do respond to, initially, is the melody's subjective genre (e.g. R\&B, disco, electronica), and these are not universally 
appreciable without a certain amount of cultural context. This refers to the subjective, culturally constructed aspect of music. This is the reason why you might prefer Bieber over Beethoven. A parallel could be drawn with cooking: the different cooking styles differ not only from culture to culture, but from generation to generation and from household to household. However, the underlying things that make for a good stew or leaven bread are more or less universal: they have comparable amounts of fat, protein, sweetness, acidity saltiness etc. Sure, some like it saltier than others, but nobody puts cup size measures of salt in their soup.

Powell explains that these subjective pieces reflect the "prototypes" that we get used to, but that we are always able to add new genres to our musical palette. "You'll need to listen to the stuff you don't initially like a few times before the new prototype takes root" but this increases your ability to appreciate a wider range of musical styles: which is exactly what one should expected from a competent critic.

We would also like our critic to have "that delicacy of imagination, which is requisite to convey a sensibility of those finer emotions", as Hume so eloquently put it. Once a critic has explained why something is good or bad a consensus should be attainable on whether the validity of the critic's verdict is good or bad, too. And this, over time, should inform us as to an expert's competence.

It would, therefore, seem that Hume was correct when he declared that the good judges "are easily to be distinguished in society, by the soundness of their understanding and the superiority of their faculties”. One may now appreciate why I felt it important to emphasize the universality of human sensory and emotional perception. And, it would also seem that Hume was correct in suggesting that the "test of time' is perhaps our only means of discerning truly great art. 
As it stands, the protectionist position condones the current situation in which music industry gatekeepers go unchallenged for concerning themselves only with gratifying consumers' desires, by using every marketing trick at their disposal. Even, if such a toxic cultural atmosphere means that talented musicians might not receive the exposure that they may in fact deserve. This top-down cultural landscape, which is increasingly being protected by legislation, is what I will be challenging in the following chapter. 


\section{Chapter 2: THE MUSIC INDUSTRY}

In the last chapter, I discussed how music is part of the essential fabric of human expression. We saw that most people who have some sort of sensibility towards the sonic arts can discern the good from the bad, but that we still look to the expertise of critics for discovering and assessing new talent. In the third chapter, I will be merging what was discussed above with what I am about to present when I explain the role that music critics and enthusiasts play in guaranteeing that worthy musicians receive their fair share of appreciation. We will now discuss the complexities of the music industry in the context of the developments leading up-to and from the appearance of the internet.

The liberal position sees music as an extension of the human character and not subject to the laws of commerce. Apart from authorship rights and musicians being paid if a third party is using their work for commercial purposes, the liberal position advocates for a more fluid approach to copyright. For instance, derivative works such as sampling one tune into another, and individuals file-sharing online should be tolerated. The music industry used to be necessary to print vinyl, distribute physical content and marketing, but now that most of these functions have been replaced by the internet, it is very hard for the recording business to justify, not only its existence, but it's moral rights over the ownership of artists' music.

Protectionists argue that if musicians cannot make a decent living directly from record sales, they may be forced to take more conventional career paths, leading them away from making music. As anybody who is serious about making art would confirm, holding down a 'nine-to-five' is not particularly conducive to the creative process. As we discussed earlier, making good art is bereft of short-cuts: it is a highly engaging 
and intellectually strenuous process that consumes a lot of time and energy. Paul Stanley, of 1970 s rock group KISS fame, was quoted on Blabbermouth.net (the "CNN of heavy metal and hard rock news") expressing the oft heard mantra that file-sharing music is outright theft:

\begin{abstract}
You can't share what you don't own. The idea that somebody is taking songs or music off the internet and taking it for free and calling it "file-sharing" is like me saying "transportation borrowing", and I steal your car. (...) When people create art with the hope of being not only accepted but also being rewarded so they can pay their rent and send their kids to school and things like that, and that doesn't happen, that's what stealing does. ${ }^{18}$
\end{abstract}

The Recording Industry Association of America (RIAA), one of the world's largest music industry advocates, echoes Stanley's words by going a step farther and presenting a dim outlook for the future:

When music labels are deprived of critical revenue due to music theft, they are forced to lay-off employees, drop artists from their rosters, and sign fewer bands. That's bad news for the industry, but ultimately bad news for fans as well. We all benefit from a vibrant music industry committed to nurturing the next generation of talent. ${ }^{19}$

If we no longer have as many musicians exclusively dedicated to their craft, conventional wisdom suggests that we will hear less quality music. If this is the case, the cultural dimension to our lives will be impoverished.

Furthermore, this is not just happening to super famous acts like KISS: it would seem, that independent labels are the ones to have been the most adversely affected by the advent of the internet. This means that non-commercially motivated musicians who were unlikely to gain mass appeal in the pre-internet age, might be getting more disproportionately affected than mainstream performers. 


\subsection{THE DEMISE OF THE RECORDING INDUSTRY}

Stephen Witt in How Music Got Free (2015) attributes the record industry's demise to three main factors:

(T)he splendid profit margins of the compact disc, the covetous attitude toward intellectual property, the indifference - indeed wilful ignorance - toward both the internet generally and the future of recording technology specifically (Witt, 56-57).

The industry went from a USD1 billion a year business in 1959 to a $\$ 4.1$ billion behemoth in less than twenty years (1978), but that would be dwarfed by the spectacular profit margins of CDs, that made their first appearance on the market in 1982. These splendid profits were bolstered by "collusion" between the "Big Five"IV record labels, who controlled almost ninety-percent of the US market, and the US's largest music retail stores not to sell disks at a discount, costing the music buying public more half a billion dollars between 1995 and 2000.

And, let us not ignore the ubiquitous 'payola scandals': a cynical business practice in which large record labels induce radio stations to play specific artists to monopolise the airwaves with their acts. This practice inevitably blocks exposure of other artists who might be more deserving of the public's attention.

Witt explains that the 1990's compact disc boom not only helped entrench the unrealistic expectations of fame and fortune still held by many aspiring performers today, but was the ultimate money spinner for the industry because they were

Iv Warner Music Group, EMI, Sony Music, BMG and Universal Music Group. 
extremely cheap to mass produce, and (at least initially) were costly and impractical to duplicate. (Ibid, 114, 196)

Steve Knopper, in Appetite for Self-Destruction: The Spectacular Crash of the Record Industry in the Digital Age (2009), explains that in the 1980s CDs cost less than one dollar per unit to manufacture but retailed for $\$ 16.98$ while, in contrast, vinyl had been expensive to manufacture and retailed for a maximum of $\$ 8.98$. Tapes usually retailed for $\$ 9.44$ (or $\$ 10.98$ for "superstar" cassettes from the likes of Madonna and New Kids on the Block), ${ }^{20}$ which was still more expensive than LPs, and cost less than CDs to make, but were easily reproduced. ${ }^{\mathrm{V}}$ Knopper: "The CD was an opportunity to change consumers' expectations about what music should cost.”

Record executives also viewed this new technology as a chance to "rejigger artists' contracts”. For starters, unless you were some extremely famous act that could 'wag the dog', the artists' royalties were reduced by 20 percent. The labels also raised the "packaging reduction" cost from ten percent or 15 percent in the LP days to "a very standard 20 percent" out of the musician's end. They also reduced the "alwaysmysterious free-goods allowance, which even experienced music business lawyers can't really define." The result was that artists were paid roughly 81 cents per CD compared to the 75 cents paid for an LP, but CDs sold for almost $\$ 8$ more than LPs, so the "typical artists made just six cents more" per CD sale.

And in many cases, this inequitable division of profits was applied retrospectively: "When they realized just how aggressively fans would replace their LP collections with CDs, label attorneys asked older 'catalogue acts' to sign new contracts with drastically reduced royalty rates.”

\footnotetext{
v Approximate worth in today's money: CD USD43 (NZD60), cassette \$24 (\$33) and LP \$23 (\$32).
} 
Quoting artist attorney Jay Cooper who has represented Tina Turner, Lionel Ritchie, and Sheryl Crow: "They did it under the guise of (the CD) being a "new technology.' But, although the CD came out in 1982 or 1983 , in some cases that reduction lasts to this day." Cooper continues: "The reality is, unless you're representing a super superstar, record companies have all the power.”

Sony's CD production plant in Terre Haute, Indiana, went from manufacturing 300,000 CDs per month in 1984, to pumping-out 850,000 CDs and 1.1 million DVDs per day in 2004 . US CD sales went from $\$ 17.2$ million in 1983 , to $\$ 103.3$ million in 1984 to its 1999 peak of $\$ 12.8$ billion per annum. Howie Klein, head of Warner-Reprise Records in the 1980s and 1990s declared: "That is the single thing that made the record industry roll in cash.” (Knopper, 31-35)

The CDs emergence was a fortuitous occasion for the Big Five as the industry was still reeling from major financial losses accrued in the late 1970s after having overextended itself by releasing too many awful disco albums... And, more importantly, there was a considerable sales slump in 1982 resulting from the introduction of the dual-head tape deck, which enabled people to make copies of original albums.

Without a hint of irony, Alan Greenspan whose sacrosanct 'trickle-down-effect' advocating for a laissez-faire approach to economics, wrote an independent analysis of how best to mitigate the emergence of audio cassettes: "Greenspan figured, the only way to reverse the sales slump was through an aggressive campaign of law enforcement against the bootleggers. In other words, the success of capitalism required vigorous intervention from the state" (Witt, 83-84). This practice is what economists refer to as 'cost externalisation': a business externalises its costs when it passes its losses on to another business or more often than not, to the taxpayer. 
The rapid proliferation of dubbed cassettes should have been interpreted as the moribund canary at the bottom of the coal mine: if people would rather buy boxes of blank tapes and listen to inferior recordings rather than pay what was asked of them, the labels should have seen this as an indicator that the price of owning music was too high, but a focus on profit margins ensured that this would be overlooked.

Cory Doctorow in Information Doesn't Want to Be Free: Laws for the Internet Age (2015) explains, that the budding film industry (who are major music rights holders) only ended up in Hollywood so that the studios could “rip off Edison's patents with impunity, but that was different".

When radio stations began to appear, and wanted to play records over the airwaves the "record industry was furious, and tried (unsuccessfully) to block radio broadcasts that lacked explicit permission from recording artists.” Doctorow also informs us that the same thing happened when cable TV came along: broadcasters argued that it was piracy, but that was also unsuccessful.

Then, there was the 1984 'Betamax' Supreme Court ruling in which cable TV operators and the studios took Sony to court over the emergence of the VCR. Their argument went along the lines of: "When we took the broadcasts without permission, that was progress. Now that someone's recording our cable signals without permission, that's piracy." Doctorow continues: "Sony won, and fifteen years later it was one of the first companies to get in line to sue Internet companies that were making it easier to copy music and videos online.”

Perhaps, the greatest irony lies with the invention of piano rolls: Composers "were aghast" that such a technology could allow player-pianos to perform their works. They tried in vain to have them classed as copyright violations. This led to the 
emergence of compulsory licensing, which is best exemplified in a radio station's right to play a song without having to get the copyright holder's permission. This, in turn, gave birth to the recording industry. (Doctorow, 145-147)

\subsection{COPYRIGHT AND LAW}

Protectionists would like to see copyright infringing websites either removed or blocked by internet service providers and search engines. They also routinely argue that individuals who partake in file-sharing should either be fined or have their internet connections disabled. This way, they argument goes, internet traffic would be rerouted to legitimate services. This would seal the 'value gap' (this refers to the gap between supply and demand: what you are willing to pay versus what the seller is willing to accept) and create revenue streams that could be redistributed to artists.

Protectionists, it must be made clear, are not motivated by self-interest of greed: quite the contrary. They too have access to illicitly obtainable content but choose instead to pay for what they procure because they want to see artists get a fair share of what they deserve.

Doctorow explains that while the inception of copyright statutes, such as the Berne Convention for the Protection of Literary and Artistic Works (1886) ${ }^{\mathrm{VI}}$ were outwardly created to protect the "moral rights" of artists over their work, a more sombre underlying need for such measures may have been overlooked: "One rationale that has never been offered is that copyright exists to protect middlemen, retailers, and distributors from being out-negotiated by creators and investors.” (Doctorow, 7)

VI The Berne Convention was one of the first international copyright agreements. 
Copyright: The exclusive and assignable legal right, given to the originator for a fixed number of years, to print, publish, perform, film, or record literary, artistic, or musical material. ${ }^{21}$

Donald S. Passman, author of what is popularly referred to as the "music industry bible" (it is in its 19th edition): All You Need to Know About the Music Business (2015), defines copyright as “a limited duration monopoly”. Copyrights differ from patents in that compositions are automatically copyrighted as soon as a tangible copy is made, whereas one needs to pay and apply for a patent from a governmental patenting bureau. 'Tangible' simply refers to a physical copy of a work or an aspect of it, this could be a demo of a song recorded on a phone or some lyrics jotted down on a napkin. Naturally, it is not enough to simply write "G A D" on a piece of paper and call that your oeuvre. For an artistic artefact to be copyrighted one needs to capture the special character of the work.

Once a composition has been physically rendered, the author has exclusive rights over its reproduction, distribution, performance, displaying and over derivative works pertaining to it (Passman cites the songs parodied by Weird Al Yankovic as an example of derivative works). However, there are exceptions to this creative monopoly: these are referred to as 'compulsory licenses'. These include guaranteeing third parties the right to play copyrighted songs on the radio, television, jukeboxes and crucially over the internet. (Passman, 225-234)

While a songwriter might automatically own all the rights to his or her work, this is the first thing they lose when signing to a major label. Doctorow: "The standard record contract gives control over 'masters' (the master recordings, key to royalties and reissues down the line) to the label." Doctorow continues: "And labels bargain for a 7 percent royalty payout on 'sales' and a 50 percent payout on 'licenses', but class 
iTunes downloads and other digital transactions as sales, keeping 93 percent of the revenue from each ninety-nine-cent track”. This is despite consumers not owning any of the songs they 'buy' from iTunes, Spotify and Pandora et al., as, according to the terms and conditions that everybody is coerced into accepting, individuals are merely licensed the works in question.

When CDs were still the mainstay "labels used to run 'third-shift' pressings" unbeknownst to artists until the Sarbanes-Oxley Act 2002 was passed in the US, which "made record company executives criminally responsible for false accounting statements". Doctorow states that this "rotten deal is largely non-negotiable, especially for new artists. Even famous and successful acts, who represent a major source of revenue for the labels, usually can't renegotiate the deals they signed starting out" (Doctorow, 45-46).

In 2001, singer songwriter Courtney Love wrote a widely circulated open letter to her "fellow recording artist" admonishing the behaviour of the Big Five labels for their exploitative actions. Love explained that despite the RIAA passing itself off as an advocate group representing the interests of recording artists, musicians have no voice: "The RIAA is a trade group that is paid for by record companies to represent their interests." This has prevented musicians from being able to negotiate for better trade terms. Love:

The royalty rates granted in every recording contract are very low to start with and then companies charge back every conceivable cost to an artist's royalty account. Artists pay for recording costs, video production costs, tour support, radio promotion, sales and marketing costs, packaging costs and any other cost the record company can subtract from their royalties. 
The reason for these unfavourable terms is because they were (and still are) applied industry wide. Sure, artists were welcome to sign with independent labels that offered fairer terms, but the problem of gaining public exposure was arguably worse before the internet than it is now (we will discuss this at length in the next chapter). This shows that a lot of the concerns faced presently by musicians are not new. Love: "Record companies advance money for recording costs and provide limited marketing services for the music that artists conceive and create. In exchange, they keep almost all of the money and 100\% of the copyrights." 22 And, because most country's copyright terms extend to 70 years after the artist is dead, it means that the bulk of all the music that has ever been recorded in human history is now owned by the (now) Big ThreeVII record labels.

Independent labels - while they are far and few between these days, due to the internet - did present artists with a viable option. They would give the musicians a larger portion of the profits and more creative control, but independent labels had a very hard time competing against the Big Five and their countless subsidiaries. Their position is even more precarious now.

For artists, it was (and still is) a toss-up between creative and business integrity, but little exposure and a limited access to audio recording facilities on the one hand, and mass marketing, a considerable money advance, networking possibilities, limos and fancy recording studios on the other. Doctorow: "the mere fact that entertainment giants are giant, slow-moving, and remorseless does not mean that they aren't also the way to make the most money while reaching the largest audience with your work." (Doctorow, 65) This is crucial point that needs to be remembered: a lot of musicians 
did make a lot of money through the studio system. But, I would argue, that those represented only the top of the tip of the iceberg.

Industry lobby groups such as the International Federation of the Phonographic Industry (IFPI), the aforementioned RIAA and the extremely powerful Motion Pictures Association of America (MPAA) that represents the interests of the major Hollywood studios (who also own some of the largest record labels in the world and the rights to thousands of movie soundtracks), have been pressing legislators in different countries not only to adopt, but also to impose American copyright laws on their citizens.

The US judiciary has shown itself to be complicit in the enforcement of US statute by stopping at nothing to imprison alleged offenders, regardless of the legislation of the country where the purported crimes took place. This was demonstrated by several high profile legal cases concerning The Pirate Bay founders Gottfrid Svartholm VIII (arrested in Cambodia), Fredrik Neij (arrested in Thailand) and Peter Sunde (arrested in Sweden), and how could we forget the extraordinary 'Armed Offenders Squad' raid on Megaupload founder Kim Dotcom, in New Zealand, that looked as though it had been directed by Michael Bay himself. And more recently, the 2016 arrest of the Ukrainian creator of Kickass Torrents, Artem Vaulin, in Poland. This challenge to another country's sovereignty by America was somewhat thwarted on 20 February 2017, when the New Zealand High Court ruled that Dotcom could not be

VIII Svartholm's response to a 2004 DreamWorks cease-and-desist letter to The Pirate Bay: “As you may or may not be aware, Sweden is not a state in the United States of America. Sweden is a country in northern Europe. Unless you figured it out by now, US law does not apply here... It is in the opinion of us and our lawyers that you are fucking morons, and that you should please go sodomize yourself with retractable batons." (Witt, 169) 
extradited for US copyright violations as he had committed no offence under New Zealand copyright laws. ${ }^{\mathrm{IX}}$

Most worrying is the influence that the Big Three (and the film studios) have on often poorly informed legislators, who struggle with the technology in their pockets, let alone something of the internet's complexity. The biggest cause for concern is the impact that the large rights holders' demands might have on the internet's neutrality (or 'net neutrality' as it is commonly referred to).

In the US, rights holders have been lobbying legislators to pass laws preventing internet service providers (ISPs) and search engines from directing traffic to illegal file-sharing websites or other entities which appear to be breaching copyright and distribution laws. As we saw earlier, this is currently protected under compulsory licenses, which also cover jukebox, radio and television broadcasts: which makes sense, as the latter have all converged onto the web.

In 2011, PIPA, an acronym for the acronym PROTECT IP Act (Preventing Real Online Threats to Economic Creativity and Theft of Intellectual Property Act), ${ }^{23}$ and SOPA (Stop Online Piracy Act) ${ }^{24}$ were introduced to the US Congress with the intent of restricting the online proliferation of copyrighted material. After widespread protests, including from tech giants and civil liberties groups, these bills were withdrawn.

While these directives may seem like reasonable requests on the part of the studios and labels, these acts could have potentially dire consequences for freedom of speech and the development of the web and human rights in general. One of the ideas being touted is the creation of a blacklist of copyright infringing websites and placing

\footnotetext{
Ix Dotcom's extradition prospects to the US now lies solely on allegations of money laundering.
} 
them behind 'censorwalls'. Censorwalls are presently used to good effect in the battle against child pornography. The problem is that these are easily breached using proxy tools like The Onion Router (TOR), so the only effective way of blocking illicitly defined searches is by keeping the blacklist secret, lest it create a 'Barbra Streisand Effect'X alerting all would be detractors (or perverts in the case of child pornography) to know what to search for.

This brings into the question the whole notion of government transparency: does that mean that we would have secret courts deciding what to block, or that the police will make those decisions on our behalf? Doctorow: "if child porn is relatively unambiguous, copyright infringement (...) is very muddy. There's no way to tell, merely by looking at a file, whether it has been put online with the authorization of the rightsholder". (Doctorow, 110-111)

Doctorow boils the issue down to one phrase: "More intermediary liability, with fewer checks and balances." (Ibid, 81) These laws could potentially coerce intermediaries all over the internet to fashion their products and services according to the interests and desires of the entertainment lobby. Doctorow:

\begin{abstract}
In the case of SOPA and PIPA, rights holders wouldn't have needed to go to court to prove infringement before getting action from web hosts, ISPs, DNS companies, payment processors, ad brokers or domain registrars - instead, they could just supply lists of businesses and individuals they'd like to see action against, and the intermediaries would have been bound to act. (Ibid, 85-86)
\end{abstract}

Under SOPA, individuals would have their service disconnected within five days for accessing copyright protected content. 25 This is even though it is almost impossible

\footnotetext{
$\mathrm{x}$ This is the phenomenon whereby trying hide something one ends up drawing attention to it. It is named after Barbara Streisand after she tried preventing photographers from publishing photos of her mansion.
} 
to determine who accessed the content in a household with multiple people using one computer, and that the many would be punished for the (perceived) crime of one. Furthermore, there are countless applications that one can use to hide their IP addresses called VPNs (virtual private networks), that people usually use to browse country restricted sites: like being able to watch the American Netflix, which has a lot more content than its foreign versions.

The likes of Google, Yahoo and Bing would be forced to remove all access to internet searches deemed illegal. ${ }^{26}$ And, according to section 103, any website on this fair planet, including individuals' Facebook pages or blogs, which accesses US content would be liable. This would also translate to Proxy tools like TOR which enables billions of subjugated people to circumvent the firewalls imposed on them by their autocratic regimes like China, Turkey and Russia. (Ibid, 84)

The Big Three: Warner Music Group, Sony Music BMG and Universal Music Group are all US based companies and they all lobby their politicians to pass laws that are in their favour. But, these laws end up affecting non-Americans all over the world. Yet, America's economic and political dominance means that their laws have a disproportionately large impact across the world. This is because they get weaved into international trade agreements, such as TPP and WTO.

For instance, Article 18 of the Trans-Pacific Partnership agreement (TPP) was exclusively devoted to strengthening such copyright agreements. ${ }^{27}$ Despite TPP not having been ratified, it is a good indicator of the sorts of measures that we might expect from future multinational copyright deals. And, even in the absence of international agreements, when it comes to the extradition of copyright infringers to America, as the 
Dotcom and The Pirate Bay raids showed, those nations that have coercible leaders are can be quite obliging to the whims of the US judiciary.

The wealth that the Big Three have accrued on the back of their underpaid musicians is not only used to erode the sovereignty of individual nations, but it places the citizens of these countries at the behest of the policies prescribed by US law makers that they have no voting power over. Not only is this immoral, but we have seen that these copyright laws are practically unenforceable. Furthermore, attempts to strengthen them are highly unlikely to benefit artists or the public. For instance, it is hard to see how musicians, culture and society are best served by overzealous copyright terms that extend to 70 years beyond an artist's life.

Today, aspiring musicians are hopefully entering the music industry with the full knowledge that if they produce a popular album, it will find itself on a peer-to-peer file-sharing website. I would argue that this is a social contract automatically entered upon when deciding to pursue a musical career. You cannot copyright recipes and in fashion one only needs to do a small number of changes to a garment to deliver it from its copyright protection, yet there's no shortage of fashion designers or celebrity chefs.

\subsection{OVERZEALOUS COPYRIGHT: A Case Study}

As I stated in my introduction, the liberal position maintains that some copyright enforcement is necessary: such as third parties exploiting a musician's work to turn a profit. But, the line should be drawn at making derivative works, like using samples or incorporating pre-existing melodies into a song. I am not qualified to elaborate on the specifics of how many percentiles constitute a 'sample', as that is a task best left to legal scholars, but there are some guidelines already in use in fashion 
that one could draw from. ${ }^{28}$ The liberal ideal on this matter revolves around determining whether a copyright enforcement serves or harms music and musicians: should it do so, it ought to be considered overzealous.

A clear example of the negative impact that overzealous copyright law has had on music, is how it has affected the evolution of hip-hop. Like rock-n-roll, hip-hop also owes its origins to African American culture. But while rock-n-roll helped remove the racial barriers - because, that's the kind of amazing thing that music does - it was the white youths who appropriated its aesthetic that were arguably the most empowered by its spirit. In contrast, hip-hop has remained the aesthetic bastion of choice for the culturally and politically disaffected and mostly coloured youths (but not exclusively so) in urban centres across the world, from LA to Manilla and Johannesburg to Paris.

Hip-hop's 'golden age' took place during the late-eighties-early-nineties. It is easily recognised by its widespread use of sampling. Because sampling on this scale was unprecedented, the licencing agreements surrounding this aesthetic were somewhat blurry. Seminal works like Public Enemy's It Takes a Nation of Millions to Hold Us Back (1988), Beastie Boys' Paul's Boutique (1989) and De La Soul's 3 Feet High and Rising (1989) all use unrelated samples from movies, commercials and completely different sorts of music in lieu of more traditional instrumentation. Wikipedia lists the more notable samples used in each of these albums' songs: Public Enemy $^{29}$ and Beastie Boys ${ }^{30}$ both use an excess of one-hundred samples each, while De La Soul ${ }^{11}$ appropriate at the very least seventy audio fragments.

The golden age of hip-hop was a place where musical genres converged, as DJs borrowed from acts as diverse as Johnny Cash, Wagner and James Brown: this meant that individual tracks and albums had the potential to gain wide ranging cross-cultural 
appeal.XI Hip-hop's modus operandi of cross-pollinating genres helped Eminem introduce British female singer Dido to worldwide audiences. Eminem sampled her song Thank You (2000) onto his top selling song Stan from The Marshall Mathers LP (2000), which sold an excess of 32 million copies.

If we consider Heavy metal, while being quite varied and having many subgenres, it still has a more integrated aesthetic consisting usually of distorted guitar, plenty of drums and a heck load of 'shredding'. Therefore, if someone is impartial to distortion (or wearing a Jack Daniels T-shirt) they are unlikely to be drawn to the metal lifestyle.

In their book Creative License: The Law and Culture of Digital Sampling (2011), Kembrew McLeod and Peter DiCola point to the devastating impact that overzealous copyright restrictions have had on this unique art form. McLeod and DiCola, quote hip-hop scholar Joe Schloss who explains that "legally, you couldn't make public Enemy's It Takes a Nation of Millions to Hold Us Back now, because the sample clearances would cost so much more than you could ever hope to make on any album" (McLeod \& DiCola, 202). McLeod and DiCola decided to evaluate this "pervasive claim" by calculating the hypothetical cost of licensing two "sample-heavy hip-hop albums” (Ibid, 203).

As their subjects, they used the aforementioned Paul's Boutique and Public Enemy's Fear of a Black Planet (1990). McLeod and DiCola: “For each sample, we obtained the sampled artist, the sampled song, and the record label of original release." Through a rigorous methodology they then determined what the respective licencing fees might cost. They took a vast array of factors into consideration, including the precisely because they sample from musical genres that I do enjoy. 
status of the songs, the labels involved, whether the sampled song took a place of prominence on the track, the duration etc. They then factored in all the external licensing costs, including what is charged by sample clearance professionals.

McLeod and DiCola make it clear that this exercise "is meant to provide an estimate of the scale of the impediments to licensing sample-based works in the collage style" and that it should not be viewed as an exact science (Ibid, 206). They also erred on the side of caution by always opting for the lowest of estimations.

The outcome is staggering: In total, Public Enemy would have lost almost USD6.8 million and the Beastie Boys would have lost an eye watering $\$ 19.8$ million on the total sales of their albums (Ibid, 201). McLeod and DiCola: "we conclude that various aspects of the licensing system - law, business practices, cost - have made at least some forms of musical collage totally impractical.” (Ibid, 212)

An entire genre of music was stopped dead in its tracks and prevented from developing due to overzealous copyright enforcement. This is evidence of short-term thinking on the part of the labels, as they could all have mutually benefited from exposing their music to such wide-ranging audiences: as Dido was when her work was appropriated by Eminem for his song Stan.

And, if one considers the amount of exposure that could have been given on the labels' respective back catalogues, it would no doubt have revived countless musical careers. These musicians could have had a second wind and gone on tours making serious money. What is even more tragic is that due to hip-hop's eclectic nature, it would no doubt have evolved into a sonic crossroads of global cultural significance, where music from all over the world could have been sampled and been granted exposure in markets that they would never otherwise have hoped to be heard. 
So much for the RIAA's earlier claim that they are in favour of a "vibrant music industry committed to nurturing the next generation of talent”. McLeod and DiCola: “Today it's cost-prohibitive to put even two - or more than two - samples in a song." (Ibid, 202)

\subsection{THE ONLINE MUSIC INDUSTRY}

Now, that we have a better understanding of what things were like before the internet, and how copyright laws work, we will look at the online music business so that we can determine whether the protectionists are right in accusing the liberal values of the internet of decimating the music industry.

The $\mathrm{MP}_{3}{ }^{\mathrm{XII}}$ file format compresses data by a factor of 1:12 using an algorithm which eliminates the audio frequencies that are beyond the typical hearing range of humans. This means that MP3s were ideal for sharing online, especially in the web's earlier days when bandwidths would have struggled to cope with Morse code.

The first time that MP3 files being shared online made the headlines in the US media, was in May 1997 (Witt, 89). But, it wasn't until Shawn Fanning created the easy to use "peer-to-peer-file-sharing-service” Napster in 1999 that the euphemistic term 'file-sharing' assimilated its present meaning. Incidentally, 1999 was also the highwater mark for the music industry in terms of sales and revenue (Ibid, 114). Napster's incarnation as an illegal file-sharing service provider was subsequently shut down in 2001, but this was just the beginning of the music industry's woes: according to a 2009

\footnotetext{
XII The MP3 file format was invented in 1993 at the Fraunhofer Society for the Advancement of Applied Research: a research facility owned by the German people to encourage the development of new technologies. (Witt, 89)
} 
estimate by the IFPI, 95 percent of downloaded music was thought to be a result of illegal file-sharing. ${ }^{2}$

According to the IFP's Music Consumer Insight Report 2016,33 35 percent of internet users access unlicensed music content, and YouTube is the number-one streaming service, with 82 percent of its visitors using it to stream unlicensed music. The IFPI report does not specify whether they do so intentionally or not, but the report states that the trend towards illegal downloads is giving way to legal forms of streaming: yes, online piracy is decreasing.

Because of drastic improvements in mobile connectivity, especially since the emergence of $4 \mathrm{G}$ networks and music streaming services, there is less need for consumers to illegally download and store music on their devices. As a result, consumers now have what amounts to their very own dedicated radio stations: the algorithms used by the streaming services find artists whose music one might enjoy, and people can also listen to other people's playlists - including lists curated by favoured DJs and critics.

Revenue on these streaming services are generated in two different ways: in the case of Spotify, they offer a free service which generates revenue by interspersing advertisement in between songs, or by offering a premium service that the consumer pays USD10 a month for. This includes unlimited ad free access and the ability to download music so that it can be listened to off-line. Pandora costs half as much as Spotify but it does not let its users pick the songs they want to listen to.

The lion's share of revenue is paid to the record label with Spotify and the artists receiving smaller cuts - in that order. IFPI report: "Globally, one-third (32\%) of 16- 
24-year-olds use paid audio streaming services. The number of 16-24 year olds paying for audio streaming has increased 39\% from a year ago.”

Regardless of the above trend, there is still a great deal of piracy going on that musicians are not being remunerated for. IFPI report: "Copyright infringement is still a major problem. Over one third (35\%) of all internet users access infringing music. The nature of infringing behaviour is changing, with stream ripping overtaking other forms of downloading." 'Stream ripping' is the practice of using a piece of illicit software to download content directly from a streaming service like YouTube, Spotify or even Netflix.

With so many versatile means of pilfering content from the web, other than making an example out of them, one could be forgiven for wondering why the US authorities wasted so much time, energy and money chasing wayward characters, like those behind The Pirate Bay, around the globe.

Even with legal streaming becoming the norm, the financial rewards for musicians appear to be dismal - if not outright exploitative on the part of the license holders and service providers. This "fundamental anomaly" is what the IFPI refers to as the "value gap". IFPI report states that this gap happened because of legal loopholes and "safe harbours" exploiting rules that were put in place in the internet's infancy to "protect truly passive online intermediaries from copyright liability". According to the media consultancy company MIDiA Research, Google owned YouTube is the biggest culprit with an estimated 800 million individuals viewing music videos on its website. This is "more than 10 times the 65 million paying subscribers to music subscription services”. 
The estimated average Spotify revenue-per user is $\$ 18$ per annum compared to YouTube's one dollar per user, per year. And, this is in context of the fact that even platforms such as Spotify generate pitiful revenue streams for their artists. Exactly how much money a musician makes every time a song is streamed depends on what was agreed to between the streaming service provider and the rights holder.

Furthermore, independently verified figures are difficult to find as negotiated terms are bound by non-disclose agreements between the record labels, streaming services and the artists. The figures that seem to come-up the most, and which The Guardian seems to stand by as having been quoted by Spotify themselves, is between \$0.006 and \$0.0084 per stream. These numbers represent the total paid to the artist(s) as well as the label. And, these are all before tax. ${ }^{34}$

According to the industry expert David McCandless on his Information is Beautiful website, for each song streamed back in 2010 on Spotify the record label made an average of $\$ 0.0016$ to the artist's $\$ 0.00029$. This means that for a musician to earn the US's average minimum back in 2010 (or now, as the US minimum wage has not increased since 2009), fans would need to stream your songs more than 4 million times every month. That's 20 million times if you were in a five-piece band. However, it's not all bad news: if you are talented and lucky enough to be the band's songwriter you would have earned an additional $\$ 0.00013$ per stream.35

Things might be improving somewhat, as according to tech site Gizmodo, Spotify is now paying out $\$ 0.00545$ per stream. $3^{6}$ This means that if you're in a fivepiece, people only need to stream your band's music 1,064,220 times per month for you to earn the minimum wage (before tax and before all of the fees charged to you by 
the record label). So, while the decrease in piracy seems to have driven up the artist's value, that's still "way less than the cost of a peanut." 37

But, the exact figures are not what is important here: all I want to show is that even if the numbers were wrong by as much as one decimal place, they would still represent a pittance to artists who share their music on these platforms, and crucially artists take home a fraction of what the labels do. To add insult to injury, what I am putting forward is probably one of the best-case scenarios: Spotify are relatively generous compared to YouTube who pay around eighteen-times less royalties to artists and labels, and they are by far the biggest online jukebox on Earth (but, as we will see in the following chapter, this is not necessarily a bad thing for artists).

In 2006, the Copyright Royalty Board (CRB), ${ }^{38}$ which is presided over by three administrative judges, was set up to redress the legal boundaries that had been blurred by the advent of the internet and live streaming. The CRB's main function was to establish the rates and terms of statutory licenses and to determine the distribution of royalties. While the inception of the CRB presents itself as a force for good, and I do not challenge here the earnestness of its intentions, the problem is that it was not conceived to take the new macro-economic reality (resulting from our current technological trajectory) into consideration.

As, a consequence of the imposition of new licensing rates across the web, independent streaming service providers were priced out of the market. This left only the big entities that already had deep pockets like Spotify, YouTube and iTunes to establish a monopoly. The reasoning behind this is that it is easier to police and enforce payments from a few providers than to chase around a countless many. 
On the surface, these copyright rules seem like an attempt to fix the age-old dichotomy of finding the right balance between protecting the financial incentives necessary to encourage creation without stifling people's ability to access the work. But, as we saw earlier, musicians create music out of passion regardless of the gilded carrots dangled before their noses. Instead, it demonstrates that we are now in the paradoxical situation wherein the commercial music business is only viable if their monopolies are propped-up by governments.

The cost/benefit decision that artists need to make is this: should the opportunity present itself, would he or she be better-off signing with a major label so that when it came to distribution and negotiating royalty rates with Spotify et al. they would get better terms and greater exposure, or should they go it alone and retain proprietary rights over their work? We will return to this in the following chapter, but it might be worth mentioning that since the deals negotiated by labels provide such meagre returns for musicians, it is hard to see what value they could add.

\subsection{A SIGN OF THE TIMES}

The reason for why so little money is generated by these streaming services is because they are competing against free peer-to-peer-file-sharing services like The Pirate Bay and the now defunct Kickass Torrents. These platforms have little or no labour costs. The peculiarity of the peer-to-peer model means that the data is stored on the devices of those infringers sharing the content. Therefore, the platforms need only minimal hardware and staff to run the sites. They are essentially just the point of contact between the people who have the file and those who want it. And, besides, these services are decentralised and have mirror copies of themselves on countless 
servers in different jurisdictions around the globe - many of which are beyond reach of the American judiciary - such as in Russia. This means that they can disseminate all matter of content from e-books to albums, and even a template for your $3 \mathrm{D}$ printer of a .22 calibre pistol made entirely of plastic known as the Liberator. XIII

This value gap can be explained according to the 'cost disease' of creating music. This is a term coined by William J. Baumol in the 1960 s who explained that people doing jobs that are difficult or impossible to automate become costlier, because those who perform these functions still need to earn wages to survive in a world where other services are becoming comparatively cheaper, due to their respective compatibility with automation.

Consider, that writing a song today takes the same amount of time as it did in 1962, because you can't teach a robot to do that, but manufacturing phones has in part been replaced by robots. Songwriters are, therefore, costlier in relation to those people who make phones. XIV

But in the case of music, this reality is compounded by the cruel fact that its very distribution has become infinitely cheaper than the cost of its manufacture. Paschal Preston and Sergio Sparviero’s 2009 study "empirically demonstrates that media content activities are stagnant, whereas activities involved in the distribution and exhibition of media content are progressive". 39 Indeed: it can take as little as three

XIII With the emergence of $3 \mathrm{D}$ printers that print using metal and silicon, we can expect a serious crackdown on file-sharing sites and nefarious search terms in to prevent people from printing machine guns, bullet casings and goodness knows what. As necessary as this would seem, how our other liberties might be affected by this is a development worth considering.

XIV This means that despite the falling price of electronics we might still be paying far too much for nonhuman produced goods (like phones and computers). This could be why large corporations are absorbing most of the world's wealth, and why the growing wealth inequality happens to have coincided with the advent of mass-automated manufacturing. In this case, taxing robots and automation as a whole and redistributing the wealth in the form of a 'basic income' would seem like a reasonable solution: in such a leisure-time-rich scenario the status of good musicians would be considerably elevated from what it already is now. 
minutes for a song to go from being released on iTunes, to finding its way on to a peerto-peer file-sharing website (Doctorow, 18).

To better understand the value gap between what purveyors of music want for and what I am willing to pay for it, let's look more closely at the cost of purchasing music before the internet and now:

I recall that when I was a teenager in the mid-nineties I used to pay NZD34.95 for a recent album on CD. In today's prices this represents $\$ 52.88$. ${ }^{\mathrm{XV}}$ Presently, once I have paid for my computer (I usually pay $\$ 1,200$ for a laptop that I expect to keep for three years: $\$ 1,200 / 36$ months $=\$ 33 \mathrm{p} / \mathrm{m})$, paid my monthly internet bill ( $\$ 75$ split three ways with my flatmates $=\$ 25 \mathrm{p} / \mathrm{m}$ ) and paid for the electricity used to power my devices (a laptop uses approximately $72 \mathrm{kWh}$, and I use mine for an average of four hours daily at $\$ 0.17 \mathrm{p} / \mathrm{kWh}=\$ 20 \mathrm{p} / \mathrm{m}$. Regarding the Wifi router, I would hazard to guess that its running costs are in the vicinity of $\$ 2 \mathrm{p} / \mathrm{m})$ : it costs me about $\$ 80$ a month to download innumerable amounts of albums, movies, books, YouTube videos, articles, recipes, .22 calibre guns, porn and access countless other data - including receiving invaluable lifestyle advice from Gwyneth Paltrow on goop.com - for less than what it used to cost me to buy two CDs: this is why there is a gap between what music sellers want for their songs and what I am willing to pay to listen to them.

Jeremy Rifkin, in The Zero Marginal Cost Society: The Internet of Things, the Collaborative Commons, and the Eclipse of Capitalism (2014), explains that technological innovation and change comes about progressively through businesses actively lowering their respective costs of production, to increase their competitive

xv According to the Reserve Bank of New Zealand's inflation calculator widget: "A basket of goods and services that cost $\$ 34.95$ in quarter 4 of 1995 would have cost $\$ 52.88$ in quarter 4 of 2016. Total percentage change 51.3\%; Number of years difference 21.00; Compound average annual rate 2.0\%; Decline in purchasing power 33.9\%; Index value for 1995 quarter 4 is 802.4; Index value for 2016 quarter 4 is 1214.0". (http://www.rbnz.govt.nz/monetary-policy/inflation-calculator) 
advantage at the price point. Rifkin: "here lies the contradiction. Capitalism's operating logic is designed to fail by succeeding." This is because price wars are a race to the bottom. Rifkin explains that: "This catch-22 is the inherent contradiction that underlies capitalist theory and practice”. (Rifkin, 7) Indeed, this is a contradiction that many economists foresaw almost a hundred years ago, including John Maynard Keynes. Rifkin: "They wondered whether, in the distant future, new technologies might so boost productivity and lower prices as to create the coming state of affairs." (Ibid, 5)

Because there are increasingly less intermediaries between products and consumers, due to ingenious inventions like computers and factory robots, vast amounts of professions and services are becoming obsolete. But, the good news is that things are become cheaper and starting to reach near zero marginal cost: such as $\mathrm{MP}_{3}$ music files.

This means that even if you were to keep within the legal boundaries, listening to Spotify's premium subscription service and watching movies and series only using Netflix etc., you would have access to more hours of content than there are hours in your month, for what it used to cost to buy two CDs. In fact, iTunes and Spotify have upwards of 30 million songs each on their respective databases: that's the equivalent of 200 years' worth of music playing all day and all night. XVI

But, this model is only effective if the market is free: free of monopolies, that is. That's because "the monopolist has scant need or inclination to bring on new laborsaving technologies to advance productivity, reduce prices, and remain competitive”. Naturally, companies cutting costs without also offering a material advantage over minutes. There are 525,600 minutes in a year. 105 million $/ 525,600=199.77$ 
their competitors would not induce customers to buy one's products and services. This means that (in theory) market driven technological evolution promotes both economic and practical advantages.

Even in the case of monopolies having an undue influence on the market, "new players invariably come along and introduce breakthroughs in technology that increase productivity and lower prices for similar or alternative goods and services, and break the monopolistic hold on the market” (Rifkin, 2-3).

In other words, one cannot stop the rising tide no matter how hard one tries. Record labels and service providers, such as iTunes, might still have an unfair influence on the market, but because the internet is literally ${ }^{X V I I}$ a copying machine, and a very cheap one at that. Therefore, short of turning democracies into police states, file-sharing copyrighted data is not going away.

Lawrence Summers, the former Chief Economist at the World Bank, US Secretary of the Treasury under Bill Clinton and President of Harvard University, along with J Bradford DeLong, a professor in economics at the University of California, Berkeley, submitted a paper at the Federal Reserve Bank of Kansas City's symposium of 2001, titled: Economic Policy for the Information Economy. In this paper, they declared that "with information goods, the social and marginal cost of distribution is close to zero". Because the advent of the web has made most uploadable content free to access, there is a decreasing amount of profitability in an increasing amount of industries.

Summers and DeLong concluded that "the right way to think about this complex set of issues is not clear, but it is clear that the competitive paradigm cannot 
be fully appropriate (...) but we do not yet know what the right replacement paradigm will be". Summers and DeLong argued that the way to proceed through this paradigm change without destroying "the entrepreneurial energy of the market", or hindering technological development was with the creation of a "temporary monopoly power", as the "profits are the reward needed to spur private enterprise to engage in such innovation" (Ibid,8).

Basically, Summers and DeLong declared that the current capitalist system doesn't work with this technology, but since we don't know what will replace it, the cautious way to proceed is to maintain some short-term monopolies. The problem with monopolies - other than the propensity they have for exploiting consumers - is that they promote inefficiency, discourage innovation, and create elites who eventually become so powerful that they wield undue influence: which usually leads to corruption and an eventual breakdown of the social fabric.

Capitalism has painted itself into a corner: with the marginal cost of so many goods and services approaching zero, skilled technicians are losing their jobs to robots, and unskilled workers are finding themselves on income support because they cannot compete against self-scanning check-out machines at their local supermarket: people's time has become the cost disease in the value gap between what we want to buy and what we are willing to work for.

However, I would not include musicians on the list of those creatures being priced out of existence, on the contrary. Musicians have everything to gain from this brave new world: never has it been easier to freely publicise one's work to a global audience without having to give so much as a penny to a record industry executive. 


\section{Chapter 3: WHY, THE INTERNET IS GOOD FOR}

\section{MUSIC}

So far, I have shown that the music industry has been going through a transformation and that the blame should not be laid at the keyboards of so called internet pirates. Instead, the liberal position maintains that we should accept that this is an inevitable result of technology's evolution.

Rather, than adapting its business model so that it more closely resembles its environment, the record business has tried to externalise its financial losses by lobbying governments to enact laws that advocate for overzealous copyright restrictions. This has resulted in individuals having been arrested, people having been labelled as thieves and millions of tax payer dollars having been squandered battling these perceived crimes. Because, government spending is limited, this drains resources away from more worthy concerns, like healthcare and education. Furthermore, we saw in the hip-hop case study that the protectionists' heavy-handed use of copyright restrictions has had a deleterious effect on music by restricting artistic expression.

Protectionists argue that it is unfair to lay the blame squarely at the feet of record executives who must make these decisions: if they do not sell music, the labels would fold and that would mean no more signings for any musicians. Surely, an imperfect music industry is better than no music industry: after all, if it weren't for the record label talent scouts we probably would never had Adele or Lorde. And crucially, consumers are free to listen to and buy what they want. As any utilitarian would point out: if music is created to have mass appeal it will be listened to by a lot more people. 
We saw earlier that music causes happiness by boosting dopamine and endorphins, so if more people listen to music that they enjoy, a priori this is a good thing because it means that there are more happy people.

The liberal in me will argue that the industry's attempt to appeal to the lowest common denominator means that many excellent performers are often overlooked simply because their music is deemed too complex or they are not deemed pretty, skinny or handsome enough. This obsession with appearance over substance has trickled down into people's lives, enculturing narcissism and a negative self-image in countless individuals.

I will also show that instead of having had a deleterious effect on the livelihood of good musicians, the web is the best means for the determined artist of getting recognition without having to endure the whims of financially motivated gatekeepers, whose judgements of taste contravene the criteria outlined by Hume.

\subsection{THE PRICE OF FAME AT ANY COST}

Despite having painted an unflattering image of the music industry, it must be noted that pouring vast sums of money into something as fickle as musical tastes and trends is a pretty high risk undertaking that requires very deep pockets. Indeed, the biggest cost to labels is "the cost of failure" (Witt, 236). Many labels lose more money on unsuccessful acts than what they spend on marketing and pressing albums for successful ones. This is why there is a tendency for record companies and producers to cobble together acts that are more likely to appeal to the lowest common denominator. 
This is precisely what a producer like Simon Cowell of $X$-Factor infamy does. Consequentially, performers are chosen by major labels solely for their ability to generate revenue and are, more often than not, usually endowed with considerable sex-appeal, whilst their music is almost always formulaic and devoid of originality - I hasten to add that this is not a point of view driven by personal bias or an ageing temperament: studies have shown that popular music has been getting considerably more homogenous. 40

Furthermore, there is also research showing that specific musical formulas have greater mass appeal than others. ${ }^{41}$ This should come as no surprise if we consider what was discussed in the first chapter, where we saw that people respond more positively to certain audio patterns than they do to others. If one's foremost priority is to guarantee a return on one's investment, it makes sense to invest in tried and tested formulas. This is not exclusive to the music industry: fast food vendors have successfully employed this method for as long as there has been a food industry.

If we look at the growing homogeneity of music, it appears that there is "less variety in pitch progressions", which means that music is losing complexity it in its structure. There is "homogenization of the timbral palette", which shows that the diversity and character of the music being made is converging because the variety of instruments and styles used to make music is diminishing. And yes, you're not just becoming old and cranky: music is getting louder (obviously, these are not mutually exclusive). The Serrà et al. study, above, refers to this deafening phenomenon as the "loudness wars". This enduring conflict probably began "with the aim of catching potential customers' attention in a music broadcast”. 
The 2014 Percino study (referenced earlier) explains that our listening habits are driven by two opposing impulses: "the demand for repetition of pleasant stimuli, and the opposing desire for variety, for change, for a new stimulus." This refers to the “optimal complexity hypothesis" put forth by a 1995 psychomusicology study that suggested that:

The different relationships of these two variables with liking are explained in terms of subjective complexity being related to objective properties of the stimuli, and familiarity being determined by cultural exposure and the subjects' own volition. ${ }^{42}$

This refers the interaction between nature and nurture where the determination of our tastes is concerned. We don't like things that are too complex or too foreign to us, and we are easily bored by things that are too simple or too familiar. This might explain why formulaic music tends to be enjoyed more by young people: having been exposed to less varieties of music due to their youthfulness, they have not yet grown overly bored by the simple compositions that so readily gratify people's inborn aesthetic biases.

According to the Percino study, commercial success seems to be heavily determined by social influences: "people showed the tendency to prefer music that they perceived was also preferred by many other listeners". I interpret this to mean that, in the general context of popular music, once our underlying biological preferences have all been met at a rudimentary level (e.g. the beat not being too fast, the complexity not being too great, the volume not being too low, the lyrics not being too weird) it is the external, societal influences (such as marketing and the "modes and fashions" that Hume spoke of) that determine what people will listen to.

Record producers understand how to 'push our buttons': they understand that marketing is a key component to convincing the public to engage with a product. And, 
as we just saw, once the formulaic boxes have been ticked, the key component separating a success from a flop is the public's acceptance of an act or what a song represents. We saw that consumers of popular music are deeply influenced by trends and are inclined to buy what others purchase. Humans are quite sheep-like in that respect, probably owing to our biological past of trying to fit-in with the group.

Major labels will employ every tactic at their disposal to get a positive return. That's why radio stations are habitually 'incentivised' to play certain tracks, and why it is not enough to be a talented musician, but that it also pays to have conventional good looks if you are to be offered a recording contract with a major label. But, this is a business practice that lends itself to the discrimination of individuals based on their appearance: none more so are affected by this than women.

The increased homogeneity we see emerging in popular music seems also to be reflected in the appearance of the acts. While an abundance of talent is probably a prerequisite for a pop star's fame, it would seem, that in most instances one need also embody an abundance of sex appeal. Surprisingly, I was unable to unearth any research which explicitly analysed the evolution of the physical appearance of pop musicians, but one need only look at Billboard's top ten female singers of 2014,43 $2015^{44}$ and 201645 respectively, to see that they do not look like typical young ladies. Either, becoming a popstar has a Cinderella like effect on one's appearance, or sexy young people are given precedence over the merely talented when it comes to being offered lucrative recording contracts.

Furthermore, it is no secret that most of these A-list performers spend a good portion of their earnings on cosmetic surgery. Indeed, the constant scrutiny that stars are put under by the tabloids and the celebrity bubble they inhabit, no doubt 
normalises such behaviour. One of the driving factors could also be the artists' understanding that their future career demands that every perceived imperfection be surgically corrected. After all, whilst many may look like 'bimbos', it is unlikely that they got to where they are by being naïve or foolish.

Not only is this a sorry state of affairs for these artists, but more crucially, normalising this sort of behaviour has been shown to have a negative psychological impact not only on their fans, but on popular culture as a whole. The hypercritical scrutiny of one's appearance often leads to poor self-esteem, bullying, eating disorders, extreme use of cosmetic surgery, and even suicide. 464748 Whilst the celebrity obsessed media seem to place a lesser degree of scrutiny on the physical appearance of men, the sorts of concerns raised above should also be extended to the masculine portion of the population.

Instead of having an industrial framework to facilitate the supply and demand of music to people for its enjoyment, pop music is increasingly being used as a vehicle for extracting money from people. This business practice disincentives producers from signing truly original or highly creative musicians. By prioritising mass appeal, the large commercially driven labels are inundating the airwaves and the world wide web with boring homogenous sounding music and crowding out more deserving artists. If people want music that will gratify them: then let them have the sonic equivalent of a Big Mac.

If one refers back to the five qualities that Hume suggests are necessary to making sound judgements of taste, one will quickly see that some of those are at odds with what one might expect from a financially motivated record industry decision maker: 
Strong sense, united to delicate sentiment, improved by practice, perfected by comparison, and cleared of all prejudice, can alone entitle critics to this valuable character; and the joint verdict of such, whenever they are to be found is the true standard of taste and beauty. (Hume, 278-279)

Whilst a “(s)trong sense, united to delicate sentiment, improved by practice, perfected by comparison" an industry gatekeeper might have, if they are motivated by profits they cannot be "cleared of all prejudice". This means that they should not be relied upon to provide the public with the best that music has to offer. Which, in turn, means that the most talented, hardworking and deserving musicians might be over looked.

\subsection{THE COMMODIFICATION OF MUSIC}

Just as there are means of determining what constitutes healthy food from junk food, we should be able to formulate a way of disentangling good music from bad. One way to do this might be to find a way of determining whether an artist is motivated solely by a desire to be famous, or by artistic excellence. The immediate problem that we encounter with this method is that good musicians also want to make good music that people like, and this might imply a certain amount of pandering to the masses and they might also want to be famous (and who could blame them). Unfortunately, this is what the formulaic music mills of major labels and shows like the $X$-Factor also try to do. I must, therefore, address this dichotomy.

Above, we discussed how the Percino study identified our listening preferences as being driven by two opposing forces: "the demand for repetition of pleasant stimuli, and the opposing desire for variety, for change, for a new stimulus". This refers to the “optimal complexity hypothesis". As we saw in the studies that I presented earlier,49 it 
was established that there is a considerable trend in commercial music towards homogeneity. In other words, these performers have an overwhelming tendency to err on the side of caution: the "repetition of pleasant stimuli". In contrast, musicians driven more by artistic ends tend to push the boundaries of what we are comfortable with, stimulating our senses with "the opposing desire for variety, for change, for a new stimulus”. I also showed that commercially driven performers have a greater tendency to look and dress alike. Therefore, their music and appearance could be said to provide a fair indicator of whether they are in it for the narcissistic pursuit of money and fame, alone, or whether they are motivated by more earnest desires.

But, because someone is driven more by artistic purity than commercial success, it does not follow that they create better music. These forays beyond the norm are not without their pitfalls: musicians often stray too close to chaos where the music is too loud, too dissonant and lacking in the minimum sonic patterns required for our brains to grasp on to. A good example of this might be certain instrumentals by Sonic Youth, whose more experimental works tend to rely too heavily on feedback, distortion and the sound of guitars hitting the ground at high velocity. Having seen them live, I must admit to it being quite an enthralling spectacle, but it is not something that I (and others) would habitually listen to independently of their other, more conventional, music.

At the other end of the spectrum we might encounter levels of sparsity and abstraction that does not do enough to stimulate our senses. One such example is John Cage's 4'33" (1952) in which no instruments are played with the object of the piece consisting only of the unplanned noises of the auditorium: such as seats squeaking and people coughing. Although witty and thought provoking, this work is appreciable only at a conceptual rather than aesthetic level. Again, this is not something one would have 
on their playlist unless they were some ill-advised art school student showing-off how avant-garde they are.

Finding this optimal complexity between chaotic energy and static order is key to creating good art. XVIII But, this is very complex as there are numerous instances in music history where innovative works have initially been ignored and even derided, only to be placed on a pedestal by the subsequent generation. We would, therefore, not wish to find ourselves admonishing such acts only to be left eating our hats twelve years later.

The Velvet Underground \& Nico (1967) is one such album: it was initially ignored but is now credited as having paved the way for the emergence of both punk rock and alternative music as two distinctive and ongoing genres. Where the opposite is concerned: Bobby McFerrin's 1988 hit Don't Worry, Be Happy comes to mind as a good example of a 'one hit wonder'. McFerrin's hit displaced Sweet Child o' Mine (1988) by Guns N' Roses from the top spot on the Billboard Hot 100 musical chart yet.50 The latter is now considered to be one of the finest rock anthems of the 1980 os by one of its finest rock bands.

So, you would need to discern between the commercial and genuine, and have the skills necessary to differentiate between that which pushes the boundaries unsuccessfully with those acts that do so successfully. The answer leads us back to the first chapter and Hume's Standard of Taste. It is the good critic can help us recognise the objective qualities underlying different works that might withstand the 'test of time'. I will come back to how this can be done using social networking, soon.

XVIII As an aside, finding the right balance between these two sides is what Friedrich Nietzsche explores in The Birth of Tragedy (1871). The two extremes are personified by Dionysus and Apollo, respectively. Nietzsche suggests that it is only when the two are reconciled that art achieves greatness. 
Interestingly, it also means that aesthetic judgements have a moral dimension to them. If I spoke of the grotesque commercialization effect the market has had on the cutlery industry, people would think that I was crazy. Yet, when one speaks of music and the arts in those terms, there is a widespread acknowledgment that these practices not only exist, but that they are unfortunate.

This is consistent with the point made in chapter one about music being inherent to human nature. This is because unlike forks and spoons, music is not a commodity. Sure: music can be commodified, but it not a 'spiritless' object like a lump of iron ore prized only for its material benefits. The kneejerk response many of us have at seeing great works exploited for financial gain appears to lend credence to the view that good art is imbued with a quality that is disposed to being personified. Nobody speaks of plumbers having to prostitute their plumbing prowess to make a living, yet we often hear of musicians being derided for 'selling-out'.

This has real implications, not least in the visual arts where the price of masterpieces has skyrocketed to such extraordinary heights that publicly owned galleries and museums are increasingly unable to acquire works of cultural significance. On the rare occasions that Manets and Monets come up for sale at Sotheby's or Christie's, they are snapped up for hundreds of millions of dollars by Russian oligarchs or Japanese tycoons to be regarded merely as status symbols alongside their super yachts and private jets. This means that the museum going public, including school groups filled with budding artists, will never be able to truly enjoy them. Anybody who has been to the Van Gogh Museum in Amsterdam can attest to the profound psychological impact seeing these original works has on a person. Such experiences do not come close to being replicated in books or slides. 
Where music is concerned, the monetisation of music places undue pressure on sincere artists to conform to what the labels want them to create. But equally as important, it has created a system which rewards marketing prowess and fickle shortterm trends over musical ability and artistic development. This merely feeds the narcissistic obsession many people (especially adolescents) have with wanting to be famous. $5^{1}$ The pitfalls of this phenomenon harps back to what was already mentioned, above, regarding the increase in cosmetic surgery, eating disorders.

Furthermore, it may possibly have the effect of treating music as a means to an end rather than something to be enjoyed and appreciated for its own sake. We need to remain mindful of the possibility that however lousy one's listening habits might be, it may spur many to learn an instrument. But, it seems more likely that by passing legislation protecting the interests of the music business, talented musicians are being crowded out by others who are prettier and have more marketing savvy than themselves. Therefore, we might be getting robbed of many beautiful musical experiences.

\subsection{CAN'T BUY ME LOVE}

In What Money Can't Buy: The Moral Limits of Markets (2012), Michael Sandel builds a case against the unbridled commodification of, well, everything. Sandel explains that the neoliberal attitude encouraging us to consider all matter of goods and services in financial terms, often has a deleterious effect on many of life's experiences. This can be damaging to the social fabric of society. Sandel: "some of the good things in life are corrupted or degraded if turned into commodities.” 
This modern era of "market triumphalism" had its genesis in Ayn Rand's Objectivism movement, but principally at the Chicago school of economics. This view is characterised as being 'neoclassical': advocating for hyper economic liberalism with minimal governmental interference. Notable proponents of this philosophy are economists Milton Friedman, Gary Becker and Alan Greenspan. Their political allies were none other than Margaret Thatcher, Ronald Reagan and Roger Douglas.

Sandel explains that "without quite realizing it, without ever deciding to do so, we drifted from having a market economy to being a market society”. A market economy is a useful tool for organising and identifying the value of things according to their perceived worth, using the supply and demand mechanism. But a "market society is a way of life in which market values seep into every aspect of human endeavour" (Sandel, 11-12).

Sandel suggests that "economics has wandered quite a distance from its original subject matter". It has gone from being about "the production, distribution, and consumption of material goods" to being "also about human interaction in general and the principles by which individuals make decisions”.

Sandel informs us that, surprisingly, "the word 'incentive' does not appear in the writings of Adam Smith or other classical economists". Sandel traces the first use of 'incentive' in the context of economics to 1943. Its usage has been growing exponentially ever since. Sandel: "Conceiving economics as the study of incentives does more than extend the reach of markets into everyday life. It also casts the economist in an activist role.” Sandel:

This is a far cry from Adam Smith's image of the markets as an invisible hand. Once incentives become 'the cornerstone of modern life', the market appears as a heavy hand, and a manipulative one. (Ibid, 85-86) 
Amongst the many examples given by Sandel is an experiment designed by two Israeli economists who tested for how monetary rewards affected high school students' motivation to collect money for charity. The result was that the two groups who had been offered varying financial incentives (1\% and 10\%, respectively) collected less than those who were offered nothing. Sandel suggests that "the introduction of market norms displaced, or at least dampened, their moral and civic commitment.” (Ibid, 118)

Citing British economist Fred Hirsch (1931-1978), Sandel explains that mainstream economists often overlook what he calls the "commercialization effect", which refers to (still quoting Hirsch):

(T)he effect on the characteristics of a product or activity of supplying it exclusively or predominantly on commercial terms rather than on some other basis - such as informal exchange, mutual obligation, altruism or love, or feeling of service or obligation. (...) The common assumption, almost always hidden, is that the commercialization process does not affect the product. (Ibid, 120-121)

Unfortunately, due to Hirsch's untimely demise, these views were not elaborated upon or presented as a viable counterpoint to the emerging view, in which money is considered as a value neutral incentive.

Fortunately, we now have a growing number of psychological studies that provide light on the commercialization effect. $5^{2}$ These studies have shown that: "When people are engaged in an activity they consider intrinsically worthwhile, offering them money may weaken their motivation by depreciating or crowding out their intrinsic interest and commitment". This is highly significant, as it runs contrary to the ideas presupposed, and taken for granted, by the standard economic theory which "construes all motivations, whatever their character or source, as preferences and 
assumes they are additive". This, Sandel concludes, "misses the corrosive effect of money" (Ibid, 122).

What we leave open to market considerations should be taken on a case by case basis, Sandel suggests. In the book's third chapter: How Markets Crowd Out Morals, Sandel explains that there are things that money cannot buy, such as friendship and love. And, there other things that money shouldn't buy.

In the latter category, he puts the novel and amusing example of a USD149 service that will write your wedding toast speech for you. XIX One merely has to fill in a few details and specify whether they would like a funny or teary-eyed speech, et voila! In this case, the yardstick that would determine the appropriateness of such a service is whether or not one would divulge the speech's origin to the bride and groom. Sandel also considers a Chinese apology service and the growing trend of receiving money as (or, is that instead of) a gift. The reason I cite these somewhat flippant sounding examples is because parallels can be drawn between what are supposed to be heartfelt displays of human affection, and the performance of music as a means of artistic expression.

Admittedly, writing a song for a television commercial serves up about as much artistic expression as a refrigerator door, and I do not mean to suggest that in instances such as these, that commercializing one's musical abilities to fulfil these ends is particularly unethical. Instead, what concerns me more is musical creations that are powerful expressions of one's identity and the human condition exploited for pecuniary ends: if we consider Jacqueline du Pré's haunting interpretation of the Kol Nidre, it would seem perverse to see it commodified in an insurance commercial.

xIx ThePerfectToast.com is now defunct. 
I understand that a possible counter-argument from the music industry could be that it is not the artworks that are being commodified, but instead it is the services and means of getting the music from the performer to the listener that drives these commercial needs. However, it stands to reason that if one is primarily motivated by the money made providing these services, a greater impetus will be placed on the saleable character of the musical work than its aesthetic merits. This means that if money is taken out of the equation, so to speak, musicians are likely to find themselves less sonically confined than they would otherwise have been.

This is what Sandel refers to as "the argument from corruption", in which money has crowded out the creativity from a lot of popular music, leaving instead formulaic works performed by phoney performers. This is why the internet has emerged at the right time: talented musicians can now bypass that entire industry and make their existence known to potential fans, themselves.

\subsection{CULTURAL CONTAGION}

Before proceeding, I would like to make a distinction between songs travelling online and memes, as one could be forgiven for thinking that they have more in common than they actually do. Left unaddressed one might consider the two as behaving similarly across social media, potentially leaving you with some unanswered questions. I can take it for granted that we are all familiar with things going viral, like that excruciating pop phenomenon from 2012, Gangnam Style by the long to be forgotten Psy. According to Wikipedia, by July 2013 it had already received more than 1.7 billion hits. But, who's listening to that now? It was a fad and everybody knew it. 
Songs spreading through social media between like-minded individuals seldom follow these sorts of bubonic cycles. Cultural trends, such as grunge in the early nineties more closely reflect what a meme is than its flagbearer Smells Like Teen Spirit by Nirvana does (notwithstanding Smells Like Nirvana by Weird Al Yankovic). Susan Blackmore explains in The Meme Machine (2000), that memes themselves are the replicators. So, grunge, by virtue of being behavioural and therefore imitable is readily considered a meme, but most popular songs, although they are often played on guitars in teenagers' bedrooms or performed in pubs before light-headed audiences, are distinct insofar as they are a case of information being conveyed for their own sake rather than a cultural trait being imitated to another end. Surfing is a meme but The Beach Boys are not, even though they contributed to the popularisation and spread of this sport.

Blackmore: "the emphasis on imitation allows us to rule out all kinds of things which cannot be passed on and therefore cannot be counted as memes" (Balckmore, 43). Thanks to its catchiness, John Williams's theme music from Jaws (1975) is at once a song and a meme. While we may have been hooked by its suspenseful tempo, it is in fact the horror that the movie evokes that is being referred to when it is mischievously sung by your brother when you are entering the ocean at night, rather than the aesthetic quality of the music for its own sake - that's despite it being an exceptionally eloquent composition. Facebook's 'like' buttons strewn across the web are memes, but most of what they share are not.

Facebook founder Mark Zuckerberg has not only had the privilege of having captained his high school fencing team and being named Time magazine's 2010 Person of the Year, but he also has a theoretical law (not unlike Moore's Law) named after him: Zuckerberg's Law. Rifkin: "Zuckerberg shows that the amount of 
information shared on the web has been doubling every year and he predicts that the doubling process will continue for the foreseeable future.” (Rifkin, 145)

This not only means that we supply Mr Zuckerberg with an increasing amount of data points to be exploited by his tireless employees for selling us increasingly targeted advertisement, but it also means that internet users' online footprints are growing exponentially wider, and intersecting exponentially more often with one another. So, not only are we becoming more connected (as the cliché keeps informing us) but we are becoming increasingly intertwined at different levels and on multiple platforms, such as Twitter, Instagram, Tinder and LinkedIn.

According to Facebook's in-house research, there are only about three-and-ahalf degrees of separation between its $>1.9$ billion users. 53 While, I would take this measure with a hefty dose of scepticism, it does serve as a good indicator of how quickly and readily like-minded groups of people can connect with each other indirectly. These connections are indirect because there are too many people on Earth to associate with directly. We connect online with like-minded people through a shared cultural rapport.

For example, if one had a passion for chess it is likely that they would be a member of at least one, or more Facebook groups dedicated to the sport, and that they would 'follow' Norway's Grandmaster of the hour: Magnus Carlsen. This implies that there could be as little as two degrees of separation between most connected chess enthusiasts. So, every time Carlsen 'likes' something using Facebook, such as a particularly delicious serving of fårikålxx from a restaurant in his native Tønsberg, his trusted followers have the possibility of being notified of this development. Amused,

xx Fårikål consists of mutton boiled on the bone with cabbage and black peppercorns. 
bemused or simply agreeing with Carlsen on his culinary choice, several of his followers would 'like' his 'like'. Before you knew it, thousands of people, many of which had never even heard of Tønsberg, Norway, would have been acquainted not only with the town but with fårikål and the restaurant whence it came.

Spotify, according to Rifkin, "can automatically post every song you listen to on Facebook. In the first few months of its introduction, 1.5 billion listens were shared through Spotify and other apps.” (Ibid, 145) So, if you decided to share a song you heard and enjoyed across social media, and you were considered to have good musical taste, the people you are networked with might also be motivated to listen to it and to share it.

A well-respected and popular music critic like Alex Ross readily gets wind of music deemed interesting through his social media and connections. If he chose to share an artist's work on Twitter with his >106-followers, the work in question would suddenly get the sort of publicity that could only have been achieved in the twentiethcentury by jumping through flaming hoops held out by the financially motivated recording industry gatekeepers.

Rifkin's Spotify anecdote highlights the ease with which one may go about publicising one's work. This networked method is the ultimate tool for mass exposure as well the best means of filtering out the good from the bad. This is because each degree of separation is directed by a living, breathing, autonomous agent, many of which have a well-developed 'delicacy of taste'. With each 'like' or 'tweet' a vote has been cast in favour of a track. This means that rather than being at the whim of the general populace, who by their numbers reflect formulaic tastes, we can picture a social media path etched out by and for music aficionados in a conscious and deliberate way, 
which would popularise the songs of those musicians deemed to be worthy of our admiration.

Furthermore, because what we share online is doubling every two years, we are introducing exponentially more data points: our lives are intersecting with more products, places, times and more importantly: people, so it means that it is getting increasingly easier for someone's music to reach those who might wish to hear it. This is because the more data points there are, the more efficiently information travels.

Admittedly, just because one is talented and writes great songs that their work will not automatically go viral if they load them up on YouTube. People can't expect to build a musical career simply by sending a link of their Soundcloud account to their local radio station. Furthermore, even if a musician manages to convince a good music critic to hear their songs, that the latter might not appreciate them. And, yes, persistence is at least as important as talent if you want people to know that you exist, ceteris paribus, other than the genes you were dealt and the people you meet, little success hinges on random factors.

The only proviso being that one must put in the work to understand how best to share things online, and they practice hard at being good musicians. If they are talented their fate does not depend on ingratiating themselves to the gatekeepers of big record labels. With social media users connected on so many different platforms it is inconceivable for musicians who are at once talented and proactive to remain obscured behind others' mediocrity.

Personal computers are now powerful enough to run very sophisticated multitrack recording programs like Pro Tools, Cubase, Ableton Live and Garageband. These coupled with good quality microphones means that artists can make some very good 
sounding demos of their work. Sure, the demos are unlikely to have a very polished or professional sounding finish, but - if recorded correctly (again, this is all about individuals working hard at developing skills and being smart about it) - they will be able to present their work in good light to potential critics or financial backers. This is where commercial studios come in: deals can be struck between musicians and studio owners where the band works-off the recording costs by touring. And thanks to tools like Google Analytics artists can determine exactly where their audience is and target those areas for shows. The internet means that bands are no longer restricted to their own backyards.

Musician Joe Pug is an excellent example of the DIY model undertaken by an artist who chooses not to rely on a big label to distribute his work. His website joepug.com is a one-stop-shop for all the content he wants to offer: one can download his albums on $\mathrm{MP}_{3}$ directly or buy them on vinyl and $\mathrm{CD}$. One can also buy his merchandise: T-shirts hats etc. He has a blog, he communicates with his audience via emails and a podcast, he has links to fellow artists, he also publishes his touring schedule as well as having a link to buy the tickets directly: bypassing the big ticket selling monopolies Ticketmaster and Ticketec (venue permitting). By analysing where the traffic to his website is coming from, Pug can target those places for shows without wasting his time and money going to places where he would not draw a crowd.

Amanda Palmer of the Dresden Dolls relates her earlier experiences as a busker to that of now being a successful, working musician. Palmer explains that while she was street performing as a "Living Statue", she "made a steady predictable income every single day”. Palmer:

People actually like supporting the artists whose work they like. It makes them feel happy.

And if you force them, they don't feel as good. (...) As long as people make art and content, 
and other people want art and content, the market will adjust to create paths for them to connect and support each other.

Palmer believes that by "putting laws into place that stop the free flow of information, sounds, and images, you mute the possibility of a real, authentic exchange" between content creators and the public. Palmer raised over USD1 million through a crowdfunding campaign so she could produce a record without having to rely on a major label.

Palmer: "The musicians I see trying to keep content locked up are generally the ones who aren't creating any new content." Palmer goes on to explain that a lot of this reticence to embrace the web comes from older musicians who see the amounts on their royalty cheques dropping every year. (Doctorow, XII-XVII)

The diminishing royalty cheques of older artists is unfortunate, but there are always transition costs to the advent of new technologies. It could also be argued that those musicians bemoaning MP3s' impact on their album sales would never have been in a position to do so had technology not been invented to record and playback music.

Furthermore, they probably benefit a great deal from a free and open internet: whether it is because the enjoy shopping on Amazon or they use Google Maps to find their way. And, that is to say nothing of all the medical and social progress the internet has enabled. So, to reap the fruits of that the web has to offer, while at the same time trying to tighten the screws on aspects of it that don't benefit them is somewhat myopic - especially in light of what I have been describing.

Artist should not only adopt, but embrace a liberal position on copyright. It is in their favour to do so. The music world is not too different to the world of chess: if you play well, people will talk about you in chess circles and you will be invited to play 
big tournaments. If you're a top-notch drummer people will hear about you and you will be asked to play in different bands. As we saw with Zuckerberg's Law, there is such a huge overlap of content being shared online that if someone failed to get the recognition that they felt they deserved, we could be forgiven for thinking they did not actually merit it. Doctorow:

People can't give you money for your art unless they know you exist. They might still decide not to give you money for your art at that point, but without fame, they don't even have to make the decision. The internet, fundamentally, is a thing that gives them a chance to do that. (Doctorow, 39-40)

Besides, simply because some fail to make a living from their music, it doesn't mean that it was a waste of time. As we saw in chapter one, music is a great tool for forming bonds between people, not least serenading would be lovers. So, there are countless reasons to make music other than to 'achieve commercial success'. Making music is not like emptying a septic tank: it is a fun and sociable undertaking - they don't call it playing an instrument for no good reason.

\subsection{THE POPULARITY CONTEST}

In Hit Makers: How Things Become Popular (2017) Derek Thompson builds a case for what I'll call the 'right place right time' argument, which emphasises the importance of unpredictability and luck in a products popularity. Thompson: "Content might be king, but distribution is the kingdom." (Thompson, 8) HitPredictor and SoundOut are just two "online song testing companies". They get thousands of individuals to evaluate new songs, giving them each a score. In the case of HitPredictor, so long as a song gets over 65.00 it has the potential to be a hit. The rest, 
according to Thompson, is exposure, exposure, exposure. Thompson: "Beyond a certain level of song writing genius, how many times audiences have heard a melody matters more for its popularity than how inherently catchy it is.” (Ibid, 37)

After having studied and met with representatives of Pandora and Spotify, Thompson explains what was earlier discussed: that people like what they are already accustomed to. We are "neophobic". Thompson adds that despite this, people also really want to be surprised. This why the big studios keep repackaging Marvel, Star Trek and Star Wars movies instead of taking risks. The trick is to serve the people up characters and worlds they are familiar with, while surprising them with new unsuspected developments, like portraying Captain America as being a Nazi (I am not being flippant: this is the latest twist in the saga).XXI

The way Spotify go about exposing their listenership to new songs is through what they call "collaborative filtering". Thompson elaborates: "collaborative because it takes many users' inputs, and filtering because it uses the data to narrow down the next thing you want to hear". (Ibid, 69) Naturally, this is all done using "an orchestra of dozens of formulas that are conducted by a metaformula.

One of the most important instruments in this algorithmic symphony is familiarity" (Ibid, 68-69). This means that the ideal "path etched out by and for music aficionados" that I presented above is great in theory. This road to success is also strewn with temporal obstacles: our desire to explore new music starts waning as we head into our thirties. Thompson: "A 2015 study of Spotify data pinpointed the precise year that listeners stop listening to new artists: thirty-three." (Ibid, 125) This might

xxI Internet piracy has a lot to do with the big studios' desire to play it safe. Because of the huge production costs involved in making even the humblest of cinema quality films (and other factors), I would be unwilling to argue that file-sharing films is morally good. In fact, I feel a great deal of nostalgia for the \$30-70 million films I used to go see, and I would quite easily have written my thesis on why piracy is terrible for good film makers. 
explain why the charts are filled with performers that seem only to be listened to by youths, despite older people having more money to spend on records and concerts.

According to Thompson, the "business of creativity is a game of chance", or to quote marketing professor $\mathrm{Al}$ Greco, the entertainment business is: "A complex, adaptive, semi-chaotic industry with Bose-Einstein distribution dynamics and Pareto power law characteristics with dual-sided uncertainty." Complex: the market is flooded with thousands of releases every year. Adaptive: when a release succeeds other producers adapt by copying it. Semi-chaotic industry with Bose-Einstein distribution dynamics: "Satyendra Nath Bose and Albert Einstein concluded that gas molecules in sealed containers would aggressively cluster at a time and place that was impossible to predict with certainty." Thompson continues: "Consider it a metaphor for pop culture, with consumers playing the role of gas molecules”. Pareto power law characteristics:

\footnotetext{
Vilfredo Pareto, an Italian economist, is credited with discovering that income within a country follows a 'power laws', such that 80 percent of wealth is held by 20 percent of the population. This Pareto principle has been extended to mean that 80 percent of sales often come from 20 percent of products.
}

Thompson adds that in "digital markets, it's even worse: 6o percent of all app store revenue comes from just 0.005 percent of companies". Dual-sided uncertainty: composers don't know what people will want to listen to and consumers have no idea what they want to be surprised by. Thompson summarises it quite nicely: "You, the creator, are making something that doesn't exist for an audience that cannot say if they will like it beforehand." (Ibid, 178-183).

Thompson goes on to challenge the notion that hits ever go viral in favour of "broadcast diffusion": a mechanism where many people get information from a single source. Citing a 2012 study in which Yahoo researchers analysed how millions of 
messages spread online, Thompson determines that on the internet "where it seems that everything is going viral, perhaps very little or even nothing is. They (Yahoo) concluded that popularity on the internet is "driven by the size of the largest broadcast."”. Thompson continues: "instead, almost all popular products and ideas have blockbuster moments where they spread from one source to many, many individuals at the same time - not like a virus".

Thompson refers to Steven Johnson's 'ghost map' which characterised London's 1854 Broad Street cholera outbreak, after which scientist John Snow falsified the miasma theory of disease. Thompson: "The popular theory of disease held that people got sick because of a spectral force called miasma - invisible poisons lofted by the winds." If you are familiar with this famous example, you will remember that after some abductive reasoning, Snow was able to infer that the outbreak stem not from this nefarious spectral gas, but from a street pump whose water had been contaminated by the cholera virus. Thompson concludes that "the disease was a broadcast".

Thompson goes on to describe "dark broadcasters" who broadcast information to many individuals at once creating "information cascades". Citing work carried out by Microsoft Research scientists, which pertained to an awareness raising video for World Malaria day in 2012, that is popularly considered to be an example something having 'gone viral', Thompson draws a different conclusion: “the video's popularity did not bloom like a virus, spreading far and wide across many generations”. Thompson continues: "The information cascade looks more like a bomb fuse - a quiet string of solitary shares followed by several explosions, in the form of celebrity tweets". Thompson maintains that this is akin to suggesting that a product has 'gone viral' after having appeared during a Super Bowl commercial. All this is to underline the difficulty that ideas, even good ones, have at gaining traction and becoming popular. Thompson 
is essentially saying that unless a 'dark broadcaster' like Justin Bieber 'retweets' your 'tweet' your idea is as good as dead. Thompson: "Words have meanings, and even the most elastic definition of virality has nothing to do with such one-to-one-thousand (or one-to-one-hundred-million) events." (Thompson, 185-196)

What Thompson maintains regarding the uphill struggle to popularise a product is a view reflected by many other experts on the subject, including Cory Doctorow, whom we discussed earlier. In fact, Doctorow believes that in many ways persistence is more important than talent (Doctorow, XXIV).

This might explain why there is an endless flow of mediocrity been routinely pumped out of radio stations and why most of it falls into obscurity, as very few works actually withstand Hume's 'test to time'. We can, therefore, agree that the importance of marketing cannot be underestimated. But, what Thompson himself underestimates is the power of the exceptionally talented to create works of beauty that are so gratifying as to prove infectious.

If the Humean view is correct, Thompson is overstating the 'right place right time' argument. He is making it sound as though once an artefact has reached a minimum threshold (such as HitPredictor's hopeful 65.00) it all comes down to "BoseEinstein distribution dynamics", which is as unpredictable as it is intuitive. What is seemingly random and unpredictable is wrongly attributed by Thompson (and most other people) to the popularisation of songs when, really it is true talent and great songs that are rare.

Yes, everything Thompson says is correct regarding formulaic art that is designed to appeal to the lowest common denominator. The big labels get manicured pop singers that have all the rightly proportioned bits in the right places to sing songs 
that were designed with HitPredictors' magic number in mind, but true talent cuts through all of this like a hot knife through butter. To suggest that the likes of Nina Simone or Bob Marley got their lucky breaks by being at the right place at the right time is to negate the obviousness of what beauty does: it shines.

Beauty captures our attention and draws us in. Beauty pushes its way into our minds intoxicating our subjective pleasure centres: lambasting our opiate receptors with large doses dopamine and endorphins. Thompson himself notes that Adele's 2015 hit Hello got a whopping 105.00 on the HitPredictor rating system. Bieber's hits of the same year Sorry and What Do You Mean? got 77.14 and 79.12, respectively. Adele's talent shone through all of the mediocrity and she attained fame not only thanks to marketing (which certainly helped), but by the power of her art.

Furthermore, it would seem that those incurable sufferers of 'Bieber fever' might actually have been struck by a miasma that is more contagious than what I might have initially been willing to accept: his relatively decent scores probably explain his relatively long-term survival on those relatively lousy music charts.

The reason so many people fail at art and music is because most people aren't special. This might be a blunt truth for many to stomach, especially in this narcissistic 'me culture' where kids are routinely put on a pedestal to be venerated like totem poles, but if talent were common would it still dazzle us?

Most teenagers do not have the determination to spend the oft cited 10,000 hours practicing their craft in order to become experts in it. 10,000 hours of playing equates to more than two-and-a-half hours of practice every day for ten years including weekends. And even if they do fulfil that criterion, they need to have the intelligence and creativity to stand-out and be original. As we discussed earlier, art is 
an excellent fitness indicator because faking that you are a good cellist requires that you learn to play the cello and become good at it. For the most part, we instinctively recognise good music when we hear it and this informs us as to the virtues of its creator. And if we aren't sure, according to Hume: critics will inform us.

What is unpredictable is where the next talented person will hail from and what they will sound like, not the ability of their work to find its way to the influential set of ears who will help popularise them. It is like walking down the street and catching a glimpse of a Ferrari, or seeing flashes of gold in a pan if you're prospecting.

Nina Simone, who began playing the piano by ear - at the age of three - had countless batons placed in her wheels for being a black woman in twentieth-century America, but there was no containing or stopping her star from rising: her genius was unavoidable. Obviously, it will be argued that there are countless geniuses that we have never heard of, and I have no doubt that this is true, but with a little bit of social media savvy and a lot of determination and persistence it is difficult to believe that if one were highly talented and proactive, that in this day and age they could not get recognition.

Thompson is also mistaken when it comes to matters of contagion: he uses the Broad Street cholera outbreak example of a broadcast diffusion where the water pump was the source of the disease, but fails to consider what went on upstream. Thompson treats the pump as the starting point when this is clearly not the case. Cholera did not spontaneously spring into existence on that spot in 1854: it spread there from someone's faecal matter infecting that source of water, and that person contracted it from another.

The same thing happens online: we all share those things that we like, such as a fan photographing Justin Bieber coming out of a swanky hair salon sporting a 
sensational haircut, and these pics get tweeted and 'liked' by individuals until someone at TMZ gets it in their newsfeed and decides to share it with TMZ's 4.57 million followers in an information cascade. Yes, it is a broadcast diffusion but it got there virally.

The Broad Street water pump is like a modern-day airport: things get serious and bad very quickly when people contaminated with Ebola or bird flu start transiting through them. Heathrow would be like TMZ's Twitter account spreading Bieber fever. Therefore, Thompson is incorrect to suggest that things do not go viral but what is important here is his highlighting the fact that for something to become known or popular it needs to be broadcasted. And, broadcasting good content is exactly what music critics and famous musicians who have big online followings do when they plug up-and-coming bands.

Ultimately, the perceived problem of piracy lies with the recording industry's top-down business model and the outdated expectations that talented musicians, like KISS's Paul Stanley, have. These older, twentieth-century musicians still have a much more proprietary conception of what copyright involves, but that's just how the cookie crumbles.

Furthermore, the protectionist mantra that 'stealing music is like stealing a car' is not applicable: the distinction being, that, if I steal your car you no longer have a car, but if I copy your album you still have it - but now I have it too. The advent of the internet has altered everything: it is a paradigm change - so the proprietary nature of copyright needs to change too.

Online piracy is not going away anytime soon, so any attempts to curb this socalled theft with heavy handed measures is not only impractical, but will come with 
many negative foreseeable and unforeseeable consequences. To affect the internet's neutrality and peoples' access to information, merely to prop-up what are essentially corporate dictatorships is highly questionable. Doctorow: "We can't stop copying on the internet, because the internet is a copying machine. Literally. There is no way to communicate on the internet without sending copies.” (Doctorow, 41)

Because we are inclined to noticing and placing value on good art, the worthy musician will eventually find their destined audience and be rewarded in proportion to the esteem in which they are held. 


\section{CONCLUSION}

I began by outlining the two opposing views, starting with those of protectionists who maintain that copyright laws need to not only be enforced but weaved into the internet's infrastructure, so that people cannot look-up infringing content. And my liberal position, arguing that copyright laws are unenforceable due to the porous nature of the internet, and that attempts to impose them has a corrosive effect both on net-neutrality, people's privacy, the aesthetic quality of music and the livelihood of musicians.

I began chapter one by giving an account of Hume's Of the Standard of Taste in which he argued that good art critics could be identified by the quality of their judgements. This implied that there are objective qualities within the arts that could be agreed upon universally as being good. It was important to show this, as I would later argue that the internet (social networks in particular) has rendered record labels unnecessary at bringing talented artists to our attention.

While people's preferences are relative, I had to show that musical excellence is not. To do this I demonstrated that good music has underlying qualities that are universally appreciable to trained ears. This also showed that music is an integral aspect of our human identity, and that it could have evolved as a social bonding mechanism and fitness indicator due to its ability to convey emotions and release neurochemicals encouraging closeness between people. This, I argued, makes music an extension of ourselves, giving it a special status that is different to human technologies.

I changed direction in chapter two, focusing exclusively on the music business. I showed that the corporations controlling the industry used musicians as means to 
making money, imposing ruthless contracts coercing musicians to sign away their copyrights just to get a recording contract and getting passed the gatekeepers who guard the airwaves. I showed that the big labels engaged in many illegal and morally questionable practices to establish and then to protect their monopolies.

I also demonstrated that the labels lobby politicians to pass draconian legislation to enforce copyright laws with potentially dire consequences to the infrastructure of the internet, as an independent platform free of corporate and governmental interference.

I explained that overzealous copyright laws have a deleterious effect on music and that musicians stand to make little to no money by signing their work to labels as online streaming services pay a trifle back to the actual creators of the works they monetize.

I demonstrated that the well-intentioned protectionist attempts to have copyright laws enforced would require censorship and the maintenance of monopolies, both of which have a corrosive effect on society. I explained that it was advisable to just accept the new reality and take a more liberal position regarding copyright.

In chapter three, we saw how the recording industry's obsession with maximising profits has not only gradually homogenised music, but has also created a toxic culture of narcissism and negative self-image in large portions of the population.

I then began reintroducing what we covered in chapter one, to show that the commodification of music is wrong and that the industry behind this has very little to offer - not only the general public, but also musicians who seek to ply their craft as a career. 
I proposed that pro-active musicians could disseminate their work effectively by performing live and using social media to get their work to influential personalities that might broadcast their songs. I demonstrated that due to beauty's impact on peoples' psyche, those talented ones who merit attention would receive it through social media and other internet mediums.

I hope that I managed to convince you that the internet, rather than having brought about the demise of the music industry, has merely decentralised it and given creative and financial control back to the artists. Musicians, can now use social media as a marketing tool for live shows and other potential revenue streams so they can earn a living doing the thing they love, and people can access music at near zero cost: this is why the internet is good for music. 


\section{BIBLIOGRAPHY}

\section{Chapter 1: THE NATURE OF MUSIC}

Arney, Kat. 'Herding Hemingway's Cats: Understanding How Our Genes Work'. London: Bloomsbury, 2016. Print.

Knopper, Steve. 'Appetite for Self-Destruction: The Spectacular Crash of the Record Industry in the Digital Age.' New York: Free Press, 2009. Print.

Beament, James. 'How we Hear: The Relationship Between Music and the Hearing Mechanism'. Woodbridge: Boydell Press, 2001. Print.

Bencivelli, Silvia. 'Why we Like Music: Ear, Emotion, Evolution'. Hudson, NY: Music World Media, 2011. Print.

Dunbar, Robin. 'Human Evolution'. London: Penguin, 2014. Print.

Griffiths, Paul. 'A Concise History of Western Music'. Cambridge: Cambridge University Press, 2006. Print.

Hume, David. 'Of the Standard of Taste', in ed. T.H. Green, T. H. Grosse, 'Essays: Moral, Political, and Literary Vol. I’. London, Longmans, Green and Co., 1898, pp. 266-284. Print.

Janaway, Christopher. 'Reading Aesthetics and Philosophy of Art: Selected Texts with Interactive Commentary'. Blackwell, Oxford, 2006, pp. 105-127. Print.

Powell, John. 'Why You Love Music: From Mozart to Metallica - The emotional Power of Beautiful Sounds'. New York: Little, Brown and Company, 2016. Print.

Thompson, William Forde. 'Music, Thought, and Feeling: Understanding the Psychology of Music'. New York: Oxford University Press, 2015. Print.

Zahavi Amotz \& Avishag. 'The Handicap Principle: A Missing Piece of Darwin's Puzzle.' New York: Oxford University Pres, 1997. Print.

1 Conard N.J., Malina M., Münzel S.C. 'New flutes document the earliest musical tradition in southwestern Germany'. Nature, 460, 2009, pp. 737-740. Journal.

${ }^{2}$ Gregersen PK, Kowalsky E, Kohn N \& West Marvin E. 'Early childhood music education and predisposition to absolute pitch: Teasing apart genes and environment'. American Journal of Medical Genetics, 12 January 2001. Journal.

3 Mithen, Steven; Morley, Iain; Wray, Alison; Tallerman, Maggie; Gamble, Clive, Review Feature: 'The Singing Neanderthals: the Origins of Music, Language, Mind and Body' by Steven Mithen. Cambridge Archaeological Journal, 2006, Vol.16 (1), pp.97-112. Journal.

4 Blasi, Damián E., Wichmannd, Søren, Hammarström, Harald, Stadler, Peter F. and Christiansen, Morten H. 'Sound-meaning association biases evidenced across thousands of languages'. Proceedings of the National Academy of Sciences, September 27, 2016, Vol. 113, no. 39. Journal.

5 Fritz et al. 'Universal recognition of three basic emotions in music'. In Current Biology Vol. 19, April 14, 2009, pp.573-576. Journal.

${ }^{6}$ Elfenbein, Hillary, Anger, Ambady, Nalini. 'On the universality and cultural specificity of emotion recognition: A meta-analysis’. Psychological Bulletin, Vol 128(2), Mar 2002, 203-235. Journal. 
7 Tarr B, Launay J \& Dunbar R. 'Music and social bonding: "Self-other" merging and neurohormonal mechanisms'. Frontiers in Psychology, 30 September 2014. Journal.

8 Pearce E, Launay J \& Dunbar R. 'The Ice-Breaker Effect: Singing mediates fast social bonding'. The Royal Society Publishing, 28 October, 2015. Journal.

9 Wermke, Kathleen, et al. 'Fundamental frequency variation within neonatal crying: Does ambient language matter?'. Speech, Language and Hearing, Volume 19, issue 4, 2016. Journal.

${ }^{10}$ Charles Darwin.'The Descent of Man, and Selection in Relation to Sex'. 1871. Print.

${ }^{11}$ Matt Ridley. 'The Red Queen: Sex and the Evolution of Human Nature'. London: Penguin, 1994. Print.

${ }^{12}$ Miller, Geoffrey. 'The Mating Mind: How Sexual Choice Shaped the Evolution of Human Nature'. New York: Random House, 2000. Print.

13 Fletcher, Garth J.O., Simpson, Jeffry A., Campbell, Lorne \& Overall, Nickola C. 'The Science of Intimate Relationships'. Chichester, West Sussex: Wiley-Blackwell, 2013. Print.

14 Dunbar, Robin. 'Human Evolution'. London: Penguin, 2014. Print

15 Higgins, Kathy, M. 'The cognitive and appreciative import of musical universals'. Revue Internationale de Philosophie, 2006, Vol.6o (238), pp.487-503. Journal.

16 Gomez, Patrick \& Danuser, Brigitta. 'Relationships Between Musical Structure and Psychophysiological Measures of Emotion.' Emotion, Vol 7(2), May 2007, 377-387. Journal.

17 Salimpoor, Valorie N; Benovoy, Mitchel; Larcher, Kevin: Dagher, Alain and Zatorre, Robert J. 'Anatomically distinct dopamine release during anticipation and experience of peak emotion to music.' Nature Neuroscience 14, 257-262, 2011. Journal.

\section{Chapter 2: THE MUSIC INDUSTRY}

Doctorow, Cory. 'Information Doesn't Want to Be Free: Laws for the Internet Age'. San Francisco: McSweeney's, 2015. Print.

McLeod, Kembrew \& DiCola, Peter. 'Creative License: The Law and Culture of Digital Sampling'. Durham, NC: Duke University Press, 2011. Print.

Passman, Donald S. 'All You Need to Know About the Music Business: Ninth Edition'. New York: Simon \& Schuster, 2015. Print.

Rifkin, Jeremy. 'The Zero Marginal Cost Society: The Internet of Things, the Collaborative Commons, and the Eclipse of Capitalism'. New York: Palgrave Macmillam, 2014. Print

Witt, Stephen. 'How Music Got Free: The Inventor, The Mogul and The Thief'. London: Vintage, 2016. Print.

18 http://www.blabbermouth.net/news/paul-stanley-says-illegal-music-downloading-is-morally-andethically-wrong-and-it-hurts-people/

19 http://www.riaa.com/resources-learning/for-students-educators/

${ }^{20} \underline{\mathrm{http}}$ ///articles.latimes.com/1990-06-23/entertainment/ca-284_1_cassette-prices

${ }^{21}$ https://en.oxforddictionaries.com/definition/copyright 
${ }^{22}$ https://www.thenation.com/article/record-toward-union-label/

23 PIPA: https://www.congress.gov/bill/112th-congress/senate-bill/968/text

${ }^{24}$ SOPA: https://www.congress.gov/bill/112th-congress/house-bill/3261/text

${ }^{25}$ SOPA, section 102(c)(2)(A)(i)

${ }^{26}$ SOPA, section $102(\mathrm{c})(2)(B)$

${ }_{27}$ The full text, including Article 18 can be found here: https://www.tpp.mfat.govt.nz/text

28 This World Intellectual Property Organization (WIPO) PowerPoint by Michele Woods and Miyuki Monroig of WIPO's Copyright Law Division, presents an interesting example of a more flexible use of copyright: http://www.wipo.int/edocs/mdocs/mdocs/en/wipo ipr ge 15/wipo ipr ge 15 t2.pdf

29 https://en.wikipedia.org/wiki/It Takes_a Nation_of_Millions to_Hold_Us_Back\#Track listing

30 https://en.wikipedia.org/wiki/Paul\%27s Boutique\#Track listing

${ }^{31}$ https://en.wikipedia.org/wiki/3_Feet_High_and_Rising\#Track_listing

${ }^{32}$ Dilmperi A., King T., Dennis C. 'Pirates of the Web: The Curse of Illegal Downloading'. Journal of Retailing and Consumer Services 18, 2011, pp. 132-140. Journal.

33 Ipsos Connect. 'Music Consumer Insight Report 2016'. International Federation of Phonographic Industry, 2016. Report.

34https://www.theguardian.com/technology/2015/apr/o3/how-much-musicians-make-spotifyitunes-youtube

35 http://www.informationisbeautiful.net/2010/how-much-do-music-artists-earn-online/

${ }^{36} \mathrm{http} / /$ gizmodetech.tk/2017/01/spotify-pays-0-00429p-per-stream/ (Gizmodo list the price at GBPo.00429 per stream)

37 http://www.gizmodo.co.uk/2017/01/spotify-pays-0-00429p-per-stream/

${ }^{38}$ http://www.loc.gov/crb/background/

39 Preston, Paschal; Sparviero, Sergio. 'Creative Inputs as the Cause of Baumol's Cost Disease: The Example of Media Services.' Journal of Media Economics, December 30, 2009. 22 (4): 239-252. Journal.

Blackmore, Susan. 'The Meme Machine'. New York: Oxford University Press, 2000. Print.

Sandel, Michael J. 'What Money Can't Buy: The Moral Limits of Markets'. New York: Farrar, Strauss and Giroux, 2012. Print.

Thompson, Derek. 'Hit Makers: How Things Become Popular'. Great Britain: Allen Lane, 2017. Print.

$4^{\circ}$ Serrà, Joan, et al. 'Measuring the Evolution of Contemporary Western Popular Music'. Scientific Reports 2, Article number: 521, 2012. Journal.

${ }^{41}$ Percino, Gamaliel, Klimek, Peter \& Thurner, Stefan. 'Instrumentational Complexity of Music Genres and Why Simplicity Sells'. PLoS ONE 9(12), 2014. Journal.

${ }^{2}$ North A. C. \& Hargreaves D. J. 'Subjective Complexity, Familiarity, and Liking for Popular Music'. Psychomusicology, 1995, Vol. 14, pp. 77-93. Journal.

43 http://www.billboard.com/charts/year-end/2014/top-artists-female 
44 http://www.billboard.com/charts/year-end/2015/top-artists-female

45 http://www.billboard.com/charts/year-end/2016/top-artists-female

${ }^{46}$ Maltby, J., Giles, D. C., Barber, L. and McCutcheon, L. E. Intense-personal celebrity worship and body image: Evidence of a link among female adolescents. British Journal of Health Psychology, 10, 2005, pp. 17-32. Journal.

47 Bissell, K. L. and Zhou, P. Must-See TV or ESPN: Entertainment and Sports Media Exposure and Body-Image Distortion in College Women. Journal of Communication, 54, 2004, pp. 5-21. Journal.

${ }^{48}$ Elliott, Anthony. 'I Want to Look Like That!': Cosmetic Surgery and Celebrity Culture. Cultural Sociology 5 (4), 2011: 463-477. Journal.

49 See: Serrà, Joan, et al.; North A. C. \& Hargreaves D. J.

${ }^{50}$ http://www.billboard.com/archive/charts/1988/hot-100

${ }^{51}$ Greenwood, Dara ; Long, Christopher R. ; Dal Cin, Sonya. 'Fame and the Social Self: The Need to Belong, Narcissism, and Relatedness Predict the Appeal of Fame.' Personality and Individual Differences, September 2013, Vol.55 (5), pp.490-495. Journal.

52 Deci, Edward L., Koestner, Richard, Ryan, Richard M. 'A Meta-Analytic Review of Experiments Examining the Effects of Extrinsic Rewards on Intrinsic Motivation'. Psychological Bulletin, 1999, Vol.125 (6), pp.627-668. Journal.

53 https://research.fb.com/three-and-a-half-degrees-of-separation/ 